Article

\title{
Scenario Analysis of Alternative Land Development Patterns for the Leipzig-Halle Region: Implications for Transport-Land-Use Sustainability
}

\author{
Eda Ustaoglu ${ }^{1}$, Brendan Williams ${ }^{2}$ and Laura O. Petrov ${ }^{3}$ \\ ${ }^{1}$ Independent researcher, Kayseri, Turkey; E-Mail: edaustaoglu@gmail.com \\ ${ }^{2}$ School of Architecture, Planning and Environmental Policy, University College Dublin, 4 Dublin, Ireland; \\ E-Mail: brendan.williams@ucd.ie \\ ${ }^{3}$ European Commission, Joint Research Centre, 1050 Brussels, Belgium; E-Mail: laura.petrov@ec.europa.eu \\ * Corresponding author
}

Submitted: 11 December 2016 | Accepted: 29 March 2017 | Published: 5 April 2017

\begin{abstract}
The objective of this paper is to present alternative land development scenarios for the sustainability impact assessment of transport-land-use relationship in the Leipzig-Halle Region. Using the MOLAND Model that was applied to a declining urban region for the first time, two different land-use scenarios were developed representing a baseline dispersed development and an alternative compact development case. The assessment of land-use-transport relationships is carried out incorporating the use of social, economic and environmental indicators. The impacts and indicators were specified and evaluated subject to a quantitative and qualitative assessment. The findings imply that a compact development scenario is preferable over dispersed development scenario in terms of potential quantitative data on the benefits to the environment and society. In contrast, dispersed development in the baseline case indicates the costs of such development exceed the benefits. The results of this type of scenario analysis provide an objective evidence basis in policy evaluation and decisions regarding future urban developments. This research was developed from several scenarios created with the key stakeholders of the Leipzig-Halle Region from research originally conducted as part of the PLUREL Project in 2012 and updated in 2016. It aims at contributing to literature by providing a sustainability assessment framework for rapid rail infrastructure provision that incorporates socio-economic and environmental impact assessment of alternative future urban form scenarios into the analysis. In addition, due to MOLAND features, it provides the opportunity for the sustainability impact assessment of different forms of urban development linked with transport infrastructure provision in the Region and compare the findings with other case study areas in Europe and internationally.
\end{abstract}

\section{Keywords}

land-use model; land-use policy; scenario analysis; transport indicators; transport-land-use sustainability

\section{Issue}

This article is part of the issue "Urban Forms and Future Cities", edited by Luca D'Acci (Erasmus University Rotterdam, The Netherlands), Tigran Haas (KTH Royal Institute of Technology, Sweden) and Ronita Bardhan (Indian Institute of Technology Bombay, India)

(C) 2017 by the authors; licensee Cogitatio (Lisbon, Portugal). This article is licensed under a Creative Commons Attribution 4.0 International License (CC BY).

\section{Introduction}

The rapid growth of peri-urban areas in many of the metropolitan centres in Europe has resulted in dispersed or scattered type of developments in contrast to the historical forms of more compact structures. The outward expansion of metropolitan areas observed both in economically strong regions and weakening core areas in Europe has been recognised as costly in social, economic and environmental terms (Girardet, 2015; Haghshenas \& Vaziri, 2012). Traffic congestion, automobile dependence, air pollution, social segregation, degradation of 
scarce land resources and decreasing quality of life are often cited as some of the most important problems faced by many of the large urban metropolitan centres (United Nations Human Settlements Programme [UNHabitat], 2013). To address some of these problems, policies such as sustainable urban development and growth management have become central both in planning theory and practice.

EU policy has for decades advocated the principles of a compact city approach to sustainable urban management as advanced in the European Spatial Development Perspective (European Commission [EC], 1999) and more recently in the New Urban Agenda adopted by the United Nations (2016). The UN promotes a specific goal to make cities and human settlements inclusive, safe, resilient and sustainable. This international policy aspiration is to promote urban consolidation and intensification and avoid the negative externalities of dispersed or sprawl type patterns of development and the resulting associated car dependency. The lack of integration of transport and land-use planning makes the realisation of such goals severely problematic and the debate continues as to whether land-use policies in isolation can be effective in influencing development and transport use patterns.

In line with such urban policy discussions, urban research also suggests that compact city is preferred to more dispersed patterns in terms of sustainable spatial development and transportation efficiency (Burton, 2013). The reason is related to the reduction in travel demand and travel time since most work and non-work activities are closely located in the compact form (Bertaud, 2004; Nelson, Dawkins, \& Sanchez, 2007). It is also argued that compact form can support public transport services better than dispersed form since population densities in the former case are high enough to provide efficiency in different modes of public transportation (K. Williams, 2005). Alternatively, other studies question the sustainability of compact form (Breheny, 2001; Westerink et al., 2013) and suggesting that decentralised or polycentric urban development solutions would be more efficient in terms of transport patterns. One reason for this enhanced efficiency cited in research is that multi-centred cities can provide significant transport benefits by locating residences close to employment centres (Simmonds \& Coombe, 2013; K. Williams, Burton, \& Jenks, 2000).

Existing planning practice provides examples of policies to achieve integrated land-use through dispersion of facilities over residential areas to achieve mixed development and pedestrian-oriented transportation (van Eck, Burghouwt, \& Dijst, 2005). Alternative strategies promoted include transit-oriented development (Jones \& Ley, 2016), containment policies (Hortas-Rico, 2015), and polycentric urban areas (Broitman \& Czamanski, 2015) which focus on various modes of transportation to support development along or near the existing public transportation axis. Both theory and planning practice suggest that accessibility to various services is an impor- tant aspect in sustainable development which could be achieved by provision of high quality and efficient transport systems.

The literature shows that the relationship between land-use and transportation is complicated since different factors such as historic urban structure, density and city size are commonly in effect in determining the transportation demand, which in turn will affect the spatial structure, density and size of the urban area (Kenworthy \& Laube, 1999). There are key theories in the literature to represent this complex relationship: the theories of urban location and urban structure are among these, which are primarily based on economic and spatial modelling of the interdependence between land rents and transportation costs. Classic theories rooted in urban economics suggest that the choice of urban location depends not only on the characteristics of economic agents and urban space, but also on the accessibility considerations (see Alonso, 1964; Mills, 1967; Muth, 1969 and others). The dynamic relationship between locational accessibility and transportation systems leads us to conclude that sustainability of the urban form and efficient transport provision are two closely interlinked subjects. In this regard, sustainability implies an urban form in which different modes of transportation are available as an alternative to private car-resulting in fewer trips-and shorter trip lengths are emphasised through the integration of land-use and transportation systems. The sustainability of a transportation system is identified as a system that provides 'access to people, places, goods and services in an environmentally responsible, socially acceptable, and economically viable manner' (Organisation for Economic Co-operation and Development [OECD], 2002).

The importance of increased travel impacts related to urban growth and transport relationships, such as traffic congestion, air/water pollution, social segregation, and urban sprawl is increasingly evident (European Environment Agency [EEA], 2006). This makes it vital to understand and encourage sustainable forms of urban development linked with provision of efficient transport services (Litman, 2016). However, urban growth no longer persists as a continuous development path in many European cities and regions (Turok \& Mykhnenko, 2007). Another aspect of development path is the urban shrinkage that is spreading extensively in Europe's old industrial regions (e.g. Northern England) and large areas of postsocialist countries in Eastern Europe (D. Haase, A. Haase, Kabisch, Kabisch, \& Rink, 2012) as well as older industrial regions in the USA. Turok and Mykhnenko also noted that, in the early 2000s, Europe had experienced an increasing number of declining cities compared to the number of growing regions. Therefore, shrinkage has become a challenging issue not only for urban policy makers and planners but also researchers aiming at understanding and coping with the causes and impacts of urban restructuring and shrinkage on economic and social welfare.

For many cities, this presents a new and uncertain development paradigm where growth, restructuring and 
now potential decline must be considered and a growth only context has to be replaced. In particular, from 2008 to 2016, the impacts of cyclical surges and corrections in property prices have been a feature of many international economies and were pronounced as the global financial crisis evolved (B. Williams \& NedovicBudic, 2016). Cities and regions in several European states-notably Spain and Ireland-were severely affected by market corrections and development. Property market collapses occurred with significant levels of unfinished and abandoned developments (B. Williams, 2014). Therefore, strategies for urban futures are sometimes required to react to new, often sudden, unexpected and unforeseen economic change. This means that flexibility in alternative planning scenarios and options chosen becomes ever more necessary.

It is accepted that a managed polycentric model may present a further alternative option and this was not covered in this research as one of the options for the chosen region. The research findings are limited to analysis of the compact and dispersed urban form options which were actively considered at research workshops with stakeholders. However, a similar methodology or approach can be adopted in future research to investigate managed polycentric and other alternative planning policy options.

An analysis of the literature on urban formtransportation relationship has shown that existing case studies in Europe were predominantly conducted in economically growing regions whereas the studies on postsocialist countries which had been characterised as declining regions are relatively scarce (Westerink et al., 2013). This study aims to fill this gap by focusing on a case study of Leipzig-Halle Region for the sustainability impact assessment of transport-land-use relationship through application of scenario analysis approach. For the sustainability impact assessment of transportation systems in cities and regions, there are various methods in the literature that consist of performance indicators, accessibility measures, commuting efficiency analysis, modal choice modelling, cost-benefit analysis, and socioeconomic and environmental impact analysis. Existing evaluation methodologies such as socio-economic and environmental impact assessments tend to be static and do not consider costs (or benefits) of alternative forms of urban development linked with provision of public (rapid rail) transport infrastructure. Therefore, the current paper aims at contributing to literature by providing a sustainability assessment framework for rapid rail infrastructure provision that incorporates socio-economic and environmental impact assessment of alternative future urban form scenarios into the analysis. The potential land development scenarios of this study were originally developed from the MOLAND (Monitoring Land-Use/Cover Dynamics) Model applications as part of the PLUREL ${ }^{1}$ Project for evaluating the impacts of dif- ferent policies and programmes on urban development considering sustainability in urban form and peri-urbanrural relationships (Ustaoglu, Williams, \& Petrov, 2012). MOLAND, for the first time, was applied to a region that had experienced a shrinkage process. This provides an opportunity for the sustainability impact assessment of different forms of urban development linked with transport infrastructure provision in the Region and comparing the findings with other case study areas in Europe and internationally.

Section 2 provides a brief overview of the case study region. Then, in section 3 , based on usage of the MOLAND Model, two scenarios for the Leipzig-Halle Region are described. This is followed by the methodology for the scenario-based impact assessment of transportland-use relationship for the case study of Leipzig-Halle Region. The results are presented and discussed in section 4, which leads to the final conclusions in section 5 .

\section{The Case Study of Leipzig-Halle Region}

Located in the federal states of Saxony and SaxonyAnhalt, Leipzig, together with the city of Halle, constitutes a polycentric urban area in eastern Germany (Figure 1). The entire region has a total population of around 1 million people, with 567,846 living in the city of Leipzig and its adjacent municipalities in December 2015, and the rest living in the Halle (Stadt Leipzig, accessed 2016).

The Region's two main urban cores, Leipzig and Halle, belong to two different federal states and are governed by various administrative bodies. These two urban core areas constitute a complete functional region and have been serving as main centres of commerce and trade since the $19^{\text {th }}$ century. There are functional relations between Leipzig and Halle varying from commuting, leisure and business activities. The Region was part of the German Democratic Republic (GDR) until 1989. Following the German re-unification of 1990, the economy of the region suffered a decline (Berkner, 2000): unemployment reached $20 \%$ in the mid-1990s and the area experienced a rapid decline in population within only 10 years time (Leipzig's population declined $12 \%$ while Halle lost $20 \%$ of population), which is linked with the economic crisis (Rink, Haase, Grossmann, Couch, \& Cocks, 2012). The Region exhibits a complex pattern of urban development considering existence of simultaneous periurban growth and shrinkage processes in different areas. The reasons of the shrinkage process are mainly related to three factors: a considerable level of out migration to Western Germany just after re-unification; a massive movement from inner core city to peri-urban areas resulting in sprawl; and a decrease in birth rates and growth in death rates (Schwarz, Bauer, \& Haase, 2011).

Leipzig's population began to stabilise from 2000 onwards, considering there has been a net positive migration in the last few years in Leipzig, following the resur-

\footnotetext{
1 Peri-Urban Land Use Relationships-Strategies and Sustainability Assessment Tools for Urban-Rural Linkages, Integrated Project of the EU 6th Framework Programme, Contract No. 036921.
} 


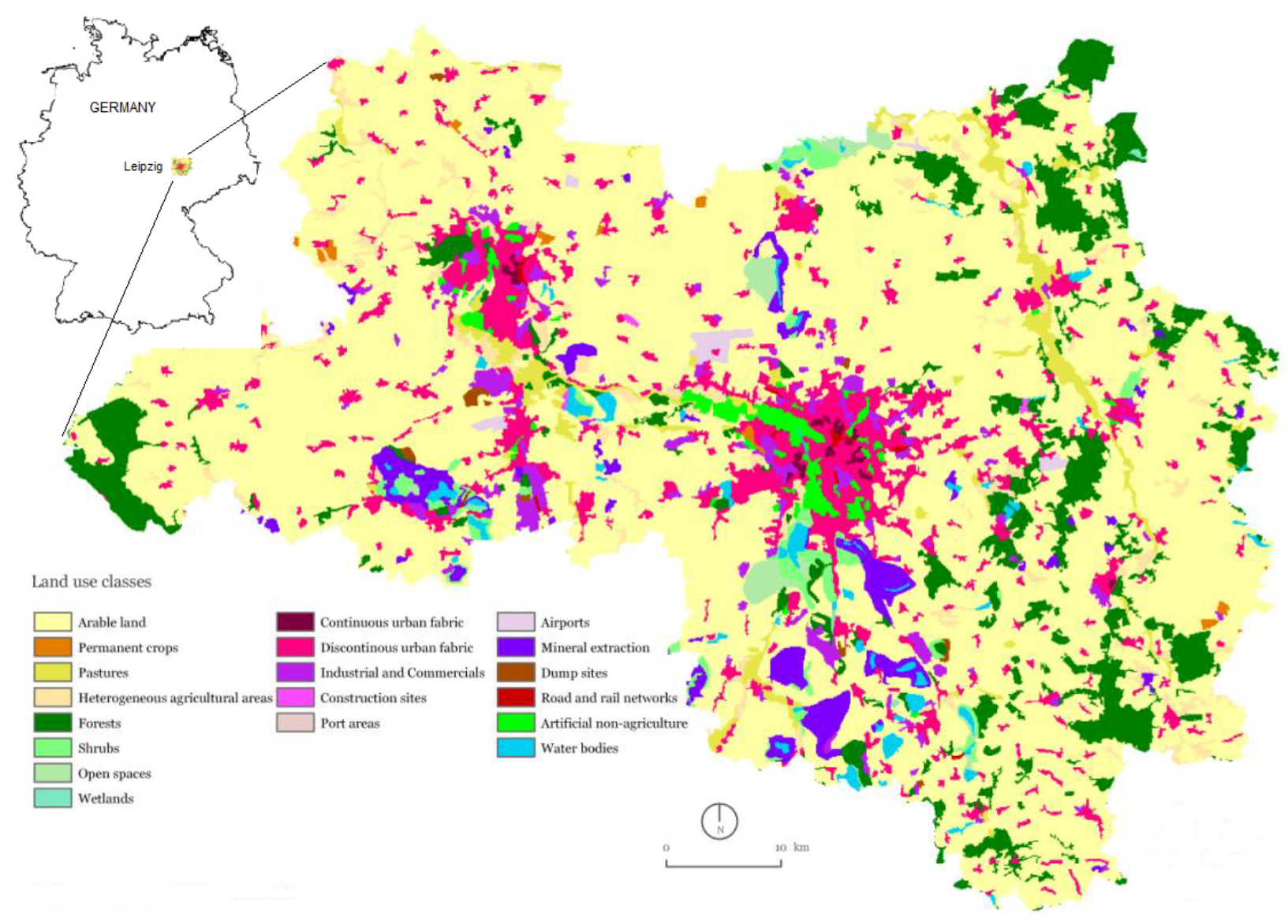

Figure 1. Land-use of Leipzig-Halle Region, 2000.

gence of the inner city started in 1999 (Schwarz et al., 2011). The population increase started on the late 1990s $(493,000$ in 2001) and reached around 525,000 inhabitants early 2011 (Großmann, Arndt, Haase, Rink, \& Steinfuhrer, 2015). The major reason behind the population growth is the in-migration, primarily from Saxony and the other eastern German federal countries. The suburbanisation process has come to a halt as formerly suburbanised areas have started to lose population to the inner city. This implies a phase of re-urbanisation in Leipzig emphasised through regaining of population in the inner-city districts that are experiencing rejuvenation and diversification of socio-demographical structure (A. Haase et al., 2010). Leipzig has been supported through considerable amount of public funds since 1990, which have mobilised private investment to the city and returned Leipzig into an attractive place for services, industrial and cultural facilities (Rink et al., 2012). Associated with the economic growth started on the 2000s, the sprawl-type pattern of development of residential and commercial uses has increased considerably along the Leipzig-Halle axis (D. Haase, Schwarz, Strohbach, Kroll, \& Seppelt, 2012). Following the dispersal of residential and commercial development initially started in early 1990s, the ongoing loss of productive agricultural areas, natural landscape and corresponding ecosystem services is critically observable.
Cities such as Leipzig and other previously industrial regions have been identified as having stabilised their populations and have seen a return to modest growth of some thousand people per year following major economic restructuring. Florentin (2010) identified the key themes in the city planning strategy for Leipzig as: first, preserving the architectural heritage, next the creation of green spaces and open spaces to replace dilapidated housing estates, and finally support for the creation of a micro-scale hierarchy of centres. In practice, these strategies were regarded as partially implemented and activated via city marketing campaigns, as the city and planners often lacked the financial and legal tools to fully implement them in pursuit of urban regeneration.

\section{Methodology}

In the frame of support to the implementation of government plans and policies in the Leipzig-Halle Region, this study develops a methodology for the transportation impact assessment of different land-use scenarios. From planners' or policy makers' view, urban planning and management pose the problem of dealing with complex systems in which social, economic and geographical factors are interrelated. Understanding the processes that cause these systems to change where activities, land-uses and spatial interactions will change-because 
of the growth potential of the system and the policy interventions-is crucial in developing effective policies (Lavalle et al., 2004). MOLAND and ASTRA-EC are the two modelling approaches integrated in this study to assist planners, policy makers and stakeholders to analyse different spatial policies and the associated spatial configurations. MOLAND consists of dynamic spatial models that operate at various spatial levels. ASTRA-EC is a four-stage transportation model that analyses Trans European Network-Transport (TEN-T) projects, and has wide area coverage in Europe. From this integrated modelling approach, the sustainability impact assessment of transportation-land-use relationship in the Leipzig-Halle Region is carried out through application of different land-use and transport-related indicators. An essential aspect of the methodology is the dynamic and cyclical interrelation between scientists, policymakers and stakeholders, supporting discussion at all stages, being adapted for territorial analysis and improved iteratively (Figure 2). This methodology of dynamic interrelation can be applied to different cities and regions at different spatial scales with an aim of supporting stakeholders and policymakers in future policy strategies.

The growth processes observed in different cities and regions often display similar characteristics; therefore geographical spaces in cities can be fundamentally similar (Batty, 2008). However, socio-economic systems that develop in cities show heterogeneities at all spatial levels and are shaped by interaction processes taking place at different geographical scales. At various geographical scales, the differences due to city-specific boundary conditions (i.e. topography and physical characteristics, geometry of transportation network, and local planning) determine the observed differences amongst cities. CAbased models aim at representing geographical systems that have heterogeneities at all levels of detail. For in- stance, CA-based models such as MOLAND incorporate interaction processes at the macro level which are beyond the cellular space of the modelled system. They also incorporate micro level attributes that represent non-homogeneous dynamic nature of the geographical space (Lavalle et al., 2004). A key element of MOLAND is the use of suitability maps which represent the capacity of a cell to support a specific activity or land-use. The suitability maps are generated in a geographical information system (GIS) and include factors such as: elevation, slope, soil, agricultural capacity, exposure to pollutants and hazards (Hagen-Zanker \& Lajoie, 2008). The MOLAND model uses suitability maps to accurately reproduce the local characteristics of an area without excluding the general context (Petrov, Lavalle, \& Kasanko, 2009). The customisation of these maps, together with the fine-tuning of other parameters, allows specific drivers to be explored. For example, using the physical suitability component of MOLAND, the outputs of a climatology model will be used for assessing future climate changes, floods, etc.

In the first step of this study, a scenario analysis approach-focusing on dispersed or more compact development cases, linked with major investments of the transportation system in the Leipzig-Halle Region-is undertaken through application of a land-use modelling approach. In the next step, a scenario-based impact assessment of transportation-land-use relationship is undertaken focusing on a number of key selected impacts and indicators representing sustainability of urban form and transportation.

\subsection{The MOLAND Model}

The MOLAND model is applied for the first time to a region which had experienced a reducing population or shrinkage process. This will provide an opportunity for an

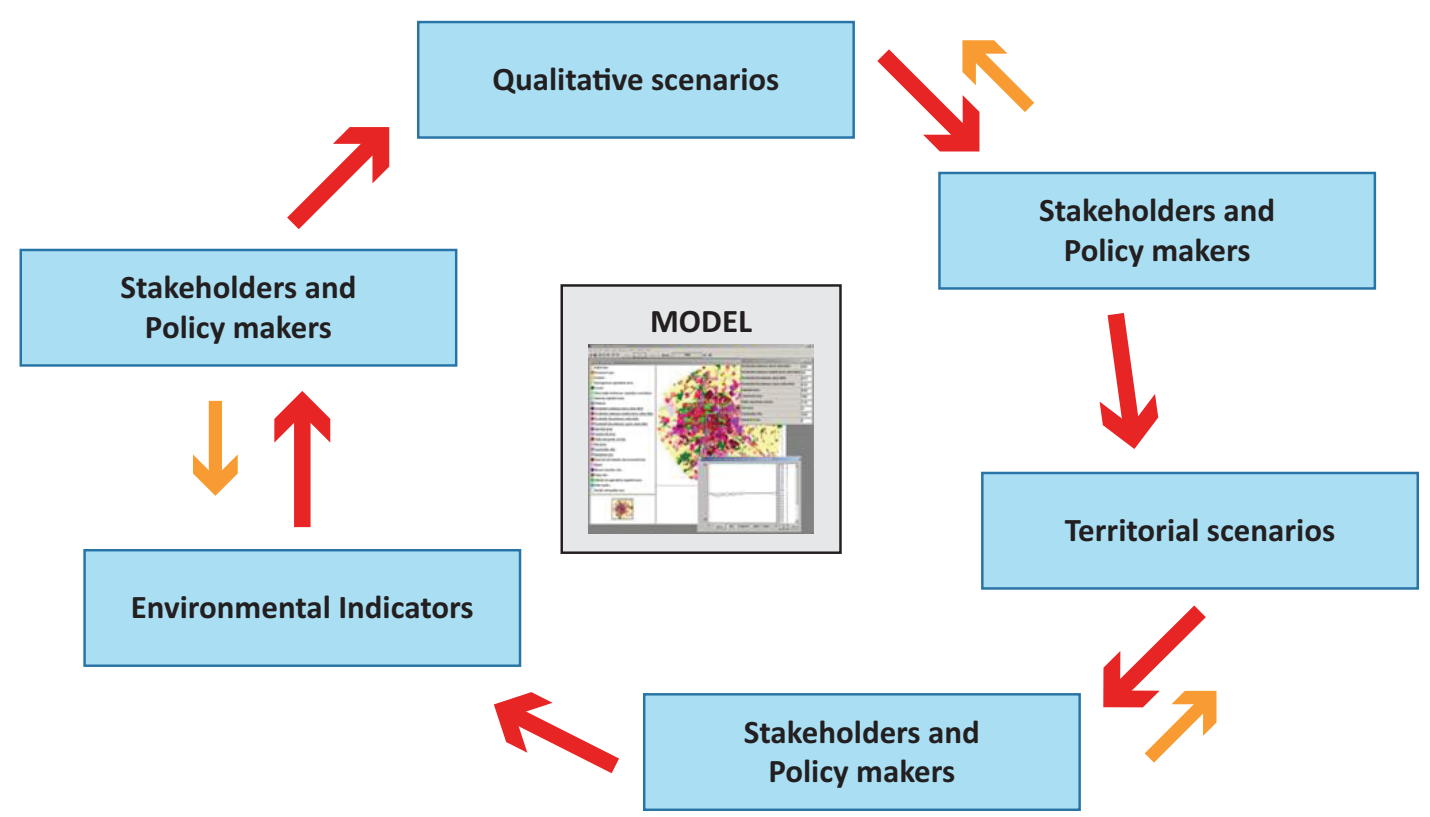

Figure 2. The model and the interrelation between stakeholders and policy makers. 
in-depth analysis regarding application of MOLAND with an increased flexibility in a variety of cities and regions. MOLAND is based on a spatial dynamics bottom-up approach and can be defined as a CA-based model (Barredo, Demicheli, Lavalle, Kasanko, \& McCormick, 2004). It is an improved version of the CA first developed by White, Engelen and Uljee (1997) and has achieved robustness through successful applications to more than $70,000 \mathrm{~km}^{2}$ in European Regions and beyond (e.g. Dublin Metropoli$\tan$ Area covering about one third of Ireland; city of Lagos, in Nigeria; Pordenone province, in Italy; DresdenPrague transport corridor; Algarve Region; Madrid; Istanbul, etc.; Petrov et. al, 2009). It has been applied in European cities, regions and beyond for urban development, regional development, transport corridors and adaptation to climate change-driven hazards. It is not the objective of this paper to give a detailed description of the model. However, we include a short overview of its characteristics. A more detailed technical description of the model can be seen in Barredo, Kasanko, McCormick and Lavalle (2003) and Barredo et al. (2004).
MOLAND integrates spatial aspects of land-use patterns with socio-economic (including transport plans), institutional and environmental features of territorial development. Also, it allows a high level of flexibility in representing the economic sectors, population development and environmental drivers, supporting very diverse sets of scenarios and planning measures (EEA, 2006). MOLAND simulates land-use dynamics and is calibrated with historical land-use information. The Model also includes a transport module ${ }^{2}$ (Barredo et al., 2003, 2004). The inputs and outputs of the MOLAND Model can be seen in Table 1. The spatio-temporal characteristics of the MOLAND output are presented in Table 2 (Shahumyan, Williams, Petrov, \& Foley, 2014).

The MOLAND Model has two key components, including regional and urban land-use sub-models. The model includes an extensive data set obtained from CORINE Land Cover (CLC) data and utilises both macroand micro-type parameters. Macro-level data such as GDP and population growth are inputs for the regional sub-model, also affecting the urban land-use sub-model

Table 1. Summary of the MOLAND Model: inputs and outputs.

\begin{tabular}{ll}
\hline Model Input and Parameterization & Description \\
\hline Land-use map & Corine Land Cover (CLC) maps showing the historical land-use/cover \\
\hline Accessibility & Accessibility of a cell to the transport network \\
\hline Zoning Status (policy) & $\begin{array}{l}\text { Master plans, zoning plans (designated areas for agriculture, housing, industry, } \\
\text { commerce, recreation etc., protected areas, historical sites, natural sites and } \\
\text { reserves, land ownership) }\end{array}$ \\
\hline Suitability & $\begin{array}{l}\text { DEM (slope, aspect), soil quality and geomorphology, natural hazards (floods, } \\
\text { landslides etc.), air, noise, water, soil pollution, agricultural capacity, subsidies etc. }\end{array}$ \\
\hline Socio-economic Data & Population, income, production, employment etc. \\
\hline Model Output & $\begin{array}{l}\text { Land-use/cover characteristics } \\
\text { Changes in urban land-use } \\
\text { Projected land-use/cover } \\
\text { digital maps }\end{array}$ \\
& Distribution of urban activities \\
\hline
\end{tabular}

Table 2. Spatio-temporal extent and resolution of the model output.

\begin{tabular}{ll}
\hline Parameter & Description \\
\hline Spatial Extent/Country Coverage & Large Urban Zone (LUZ) NUTS-2 (Region) \\
\hline Spatial Resolution & $100 \times 100 \mathrm{~m}$ or higher \\
\hline Temporal Extent & Yearly time step; Projections for 10, 20, 50 years \\
\hline Temporal Frequency & Yearly \\
\hline
\end{tabular}

\footnotetext{
2 The MOLAND transport model is based on a classical four-step transportation model, which requires transport zone maps of the region as well as data on transport flows between those zones. The MOLAND transport model is a dynamic model where the land-use model serves as an input to the transportation model, and in turn the transportation model influences the land-use model by means of a local accessibility term. The number of people and jobs per zone are used to calculate production and attraction of each transport zone. Based on these travel demands and inter-zonal transportation costs, trips are assigned to the transport network. Transportation costs are represented as an aggregate measure of distance, travel time and other transport costs. These costs are incorporated in the regional model as interregional distances affect the distribution of land-use functions across the regions. At the local level, the potential for certain land-uses is determined by their local accessibility i.e. the distance to the transport network (for details, see Research Institute for Knowledge Systems [RIKS], 2007).
} 
that is run through a CA model. Since the data incorporated in the Model come from a disaggregated data set, the micro-model parameters (i.e. neighbourhood effects, accessibility, suitability, zoning, population, employment indicators) can be utilised to explain the micro-level spatial issues, which diverge the model from those incorporating aggregate data sets and rely on large geographic districts (see Barredo et al., 2003).

However, the CLC data is not a prerequisite for the application of the MOLAND Model. For example, for the Lagos case study, MOLAND made use of high-resolution satellite imagery, aerial photographs and other ancillary data. The minimum mapping unit is 1 hectare $(100 \times 100 \mathrm{~m})$ and the land-use datasets comprise forty land-use classes. The detailed methodology for the GIS database production to be used in MOLAND model is provided in EEA (2002).

The main variable of the model is the land-use (raster) map, and the state of every cell is its land-use class (e.g. residential, industrial and commercial, forest, agricultural). The development of each land-use class is defined by four factors:

1. Physical Suitability, represented by one map per land-use class, describing the degree to which the cell fits to support a particular land-use function and the associated economic or residential activities;

2. Zoning, represented also by one map per land-use class for different planning periods and the associated economic or residential activities;

3. Accessibility, represented by one map per land-use class determining the direction to which the particular land-use function and associated economic or residential activities can respond to the cell's needs for transportation and mobility given the underlying transportation system;

4. Dynamic impact of land-uses in the area, determined by so-called 'transition rules' or weighting parameters which specify the interaction between neighboring land-use types (the attraction or rejection of a cell and its immediate surroundings: 196 cell neighborhood). The transition rules change each cell to the state for which it has the highest potential; each cell will receive a weight according to its state and distance from the central cell, beginning with the highest ranked cell and proceeding downwards. However, it is subject to one constraint: the number of cells for a land-use at a given time must be equal to the total number of cells demanded for that land-use, at that time (Barredo \& Demicheli, 2003).

The consequences of trends, shocks and policy interventions over a long period of time are visualised by means of dynamic year-by-year land-use maps as well as spatially explicit socio-economic and environmental indicators represented at high spatial resolution. In relation to capturing the elements from descriptive scenarios and how they are translated into in the model, expanded explanations are given in the 'Ingesting narrative storylines in the model' section and Appendix A of Petrov et al. (2009).

Regarding Leipzig-Halle Region, these maps were generated in a GIS environment, including factors such as: elevation, slope, aspect, soil type and existing landuse. In MOLAND, the suitability values are expressed on a scale of 0 (completely unsuitable) to 10 (highly suitable), and were computed for all the land-uses (residence, industry, commerce, services, agriculture, forest, semi-natural vegetation, ports, etc.) that are simulated in the Model. For instance, cells that are adjacent to water bodies are highly suitable for port related uses, and are assigned with the highest suitability values (values greater than 9). The land-uses adapted from CLC data comprise nineteen land-use classes that were divided in three groups (see Table 3): vacant features (areas where expansion can happen), active functions (the most dynamic areas that can determine urban growth) and fixed features (where land-use change is constrained) (Lavalle et al., 2009).

MOLAND simulates zoning with binary options, i.e. 0 is assigned to a cell that is permitted for development while 1 is assigned to those where it is not. Zoning specifies whether a cell may or may not be developed for a specific land-use function during the simulation time period. The zoning maps were developed from master plans and zoning plans that have been produced by local governments in the Leipzig-Halle Region. Land-use development policy is steered by the designation of land-use

Table 3. Land-use classes for Leipzig-Halle Region.

\begin{tabular}{lll}
\hline Vacant features & Active functions & Fixed features \\
\hline Arable land & Continuous urban fabric & Airports \\
Permanent crops & Discontinuous urban fabric & Mineral extraction sites \\
Pastures & Industrial and commercial & Dump sites \\
Heterogeneous agricultural areas & Construction sites & Water bodies \\
Forests & Port areas & Artificial non-agricultural sites \\
Shrubs & & Road and rail networks \\
Open spaces & & \\
Wetlands & & \\
\hline
\end{tabular}


objectives specific to land within the planning authorities' jurisdiction.

In addition to suitability and zoning, accessibility to transportation networks is a key input in the MOLAND Model. The existing road and rail networks in the LeipzigHalle Region were used to create accessibility maps to represent the relative importance of access to the transportation networks for different land-uses in the model.

The methodological approach used for simulating land-use changes in Leipzig-Halle Region can be summarised (Figure 3) with the following steps (Lavalle et al., 2009):

1. Definition of scenarios by local stakeholders;

2. Compilation of input data (land-use maps for 1990 and 2000, transport network, zoning and suitability maps, socio-economic data such as GDP and population);

3. Calibration of the MOLAND (for the 1990-2000 period);

4. Running the MOLAND model under different scenarios;

5. Production of outputs (land-use maps and statistics);

6. Running the ASTRA-EC Model to develop accessibility related indicators from the transport model;

7. Evaluation of the results.

\subsection{Scenarios for the Leipzig-Halle Region}

A number of scenarios were developed with the key stakeholders of the Leipzig-Halle Region, in line with the work conducted as part of the PLUREL Project between 2009 and 2012. It followed the building scenario methodology described in Petrov et al. (2009). This work has been reviewed and updated in 2016 to be considered and evaluated in the current paper. Within the framework of the current study, two likely scenarios are considered that incorporate a dispersed and a more compact development pattern in the Region linked with transport infrastructure investments. In this respect, the transportation-land-use relationship in Leipzig will be evaluated considering a hyper-tech scenario (H-TS) and a transport scenario (TS), each developed with the assistance of the MOLAND Model. The main driver of the two scenarios is transport accessibility linked with the public transportation network, which influences development patterns (dispersed or compact) of the area. In the H-TS of dispersed development hyper-tech sectors are strongly encouraged, while in the TS of more compact development transport logistics, rapid development of tourism, manufacturing and services sectors are strongly supported. In the latter scenario it can be followed that due to better transport linkage there is significant improvement in travel time and number of accidents as well as a tendency of increasing areas of agricul-

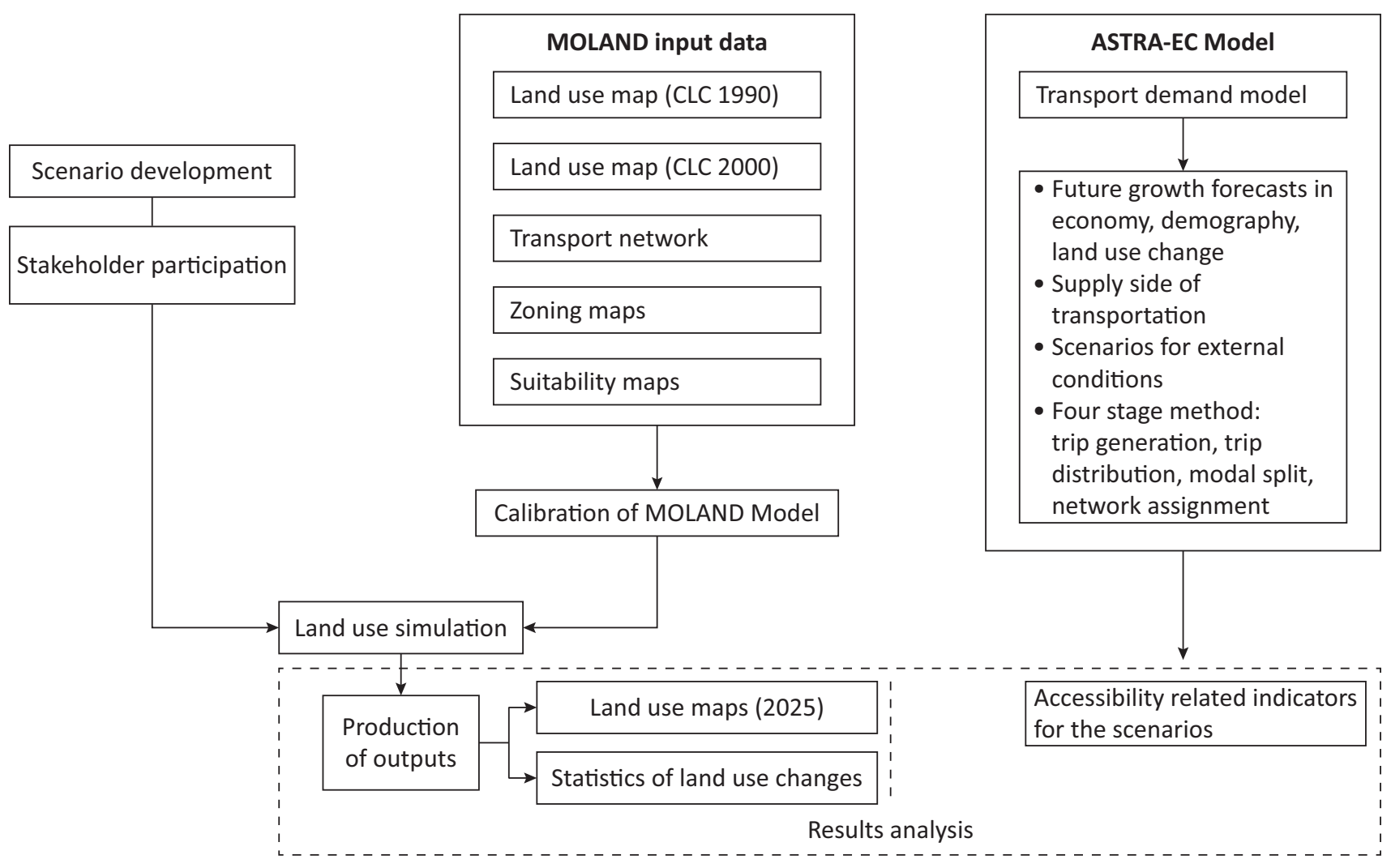

Figure 3. Land-use and transport modelling methodology. Adapted from Fermi, Fiorello, Krail and Schade (2014) and Lavalle et al. (2009). 
tural and green land (and decreasing discontinuous urban fabric area). Further details of the assumptions and results related to each scenario are shown in Tables 4 and 6 , and briefly explained in the following sections.

\subsubsection{Scenario 1: Hyper-Tech Scenario}

This scenario is characterised by prioritising and facilitating a development leading to rapid technology advance and consequent growth in the economy with investment in transportation and infrastructure improvements. New industrial and commercial growth takes place in the entire area with this growth directed to Halle and other towns located south from Leipzig (Figure 4). This increase in growth has mainly an impact on arable land, pastures and heterogeneous agricultural areas. In 2025, these changes are reflected by the land-use patterns due to considerable changes in industrial and commercial areas and construction sites (increases of $98 \%$ and 195\%, respectively; Figure 5). This increase in urban fabric has resulted in a more than $20 \%$ reduction in the heterogeneous agricultural areas and pastures, and a $1.5 \%$ reduction in arable land.

The most important feature of this scenario is the insufficient provision of rapid rail or other transit infrastructures, which is linked with urban growth in the form of dispersed settlements. The failure to provide adequate transport investment can have a double effect on de- velopment patterns. First, new developments will be located in areas with existing weak infrastructure in a dispersed manner and second, this development will lead to increased levels of poor transport accessibility. There are minor improvements in the national roads and provision of links and extensions to the motorways and airport. Rapid rail investments will not take place or will be performed in the long-term. The absence of these investments in the short-term, passive management of urban development and low environmental protection in this scenario all contribute to dispersed urban development.

\subsubsection{Scenario 2: Transport Scenario}

In this scenario, it is presumed that land-use changes are constrained by high energy prices. Despite the demographic and economic growth (Table 4), the allocation of economic activities is influenced by inherent costs of energy. Population increase due to in-migration of young people contributes to the expansion of residential areas, leading to a densification of the urban fabric. Demolished residential areas will be replaced by new residential uses and other land-uses, which leads to an expansion of the existing urban area (Figure 6). The replacement of brownfield sites with new land-uses will contribute to a compact urban form since these sites are mainly located in the inner-city areas. New clusters of discontinuous urban areas locate close to industrial and commercial areas,

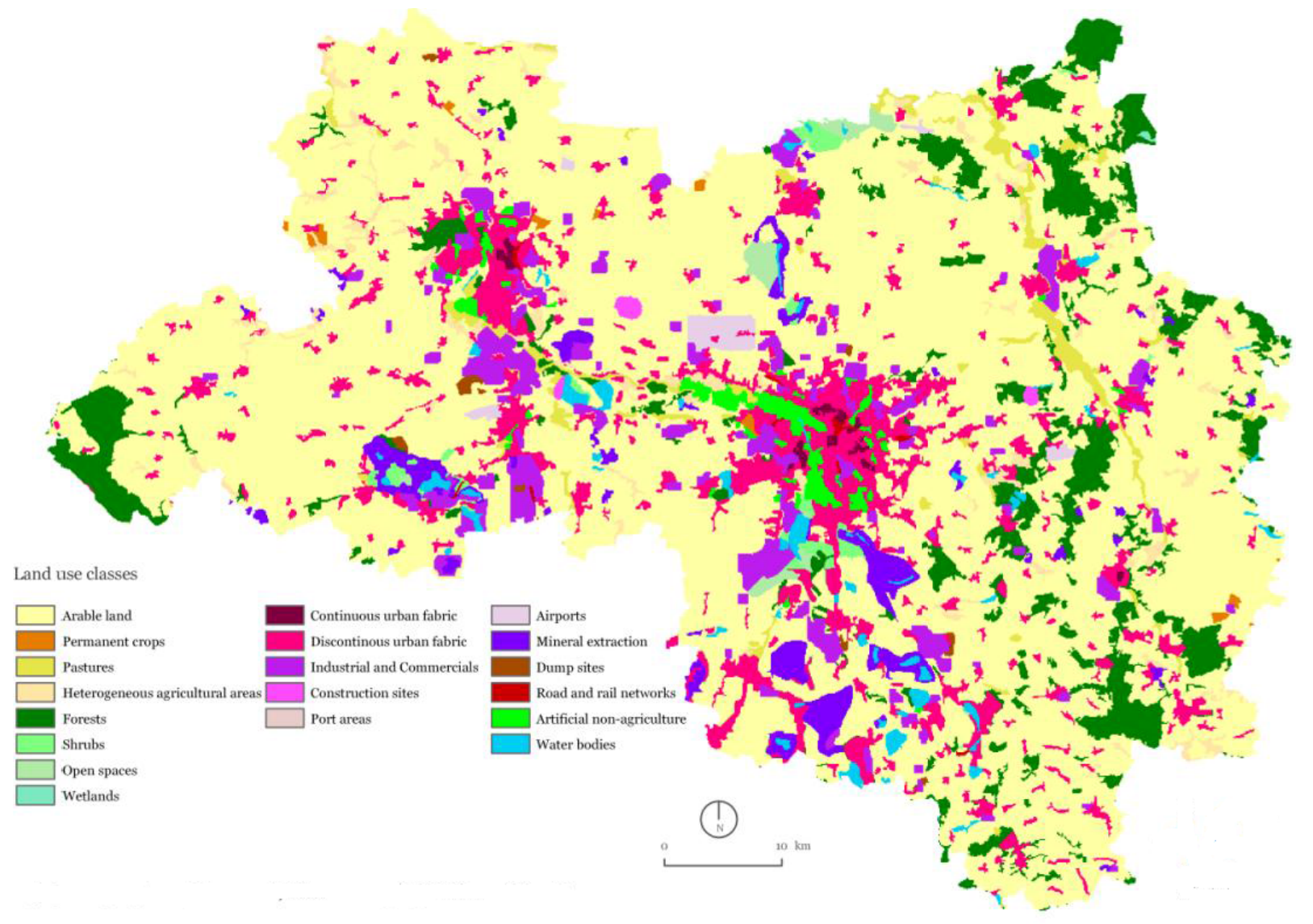

Figure 4. Leipzig 2025: Hyper-Tech Scenario. 


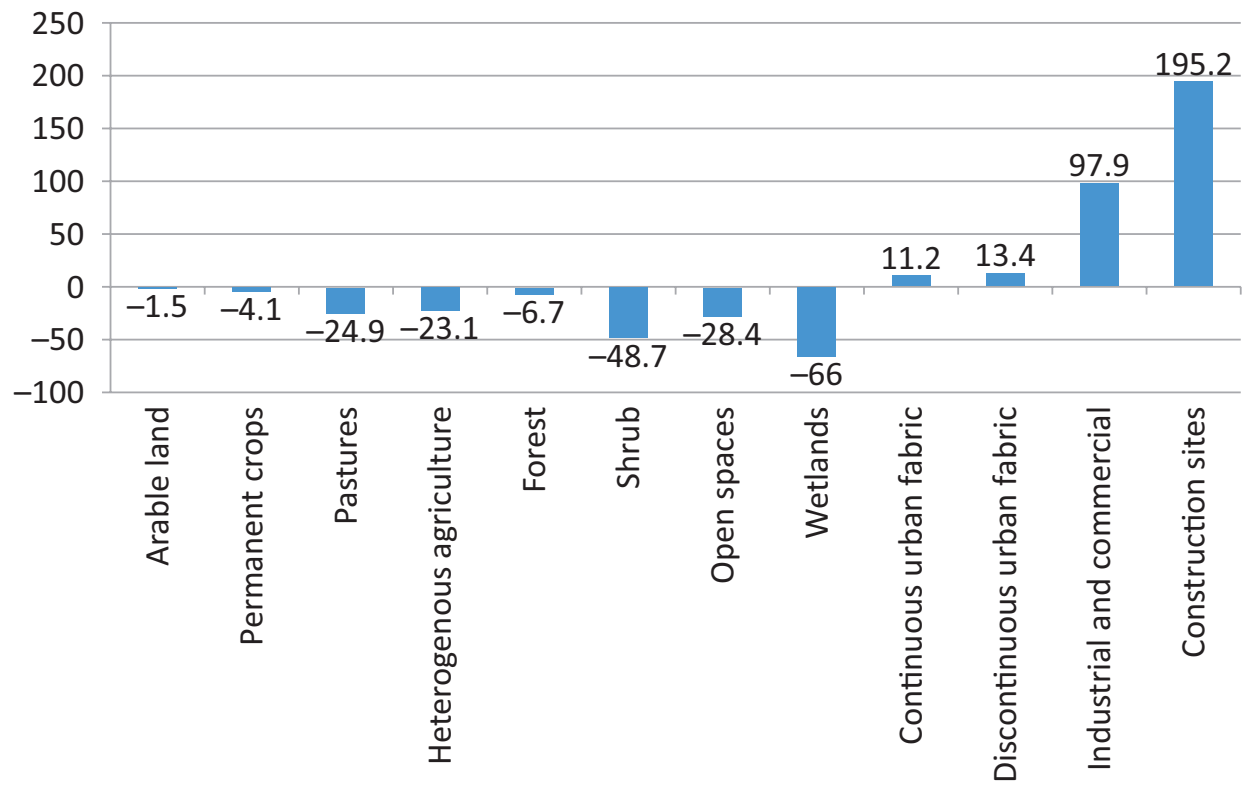

Figure 5. Percentage change of land-use classes in Hyper-Tech Scenario (2000-2025).

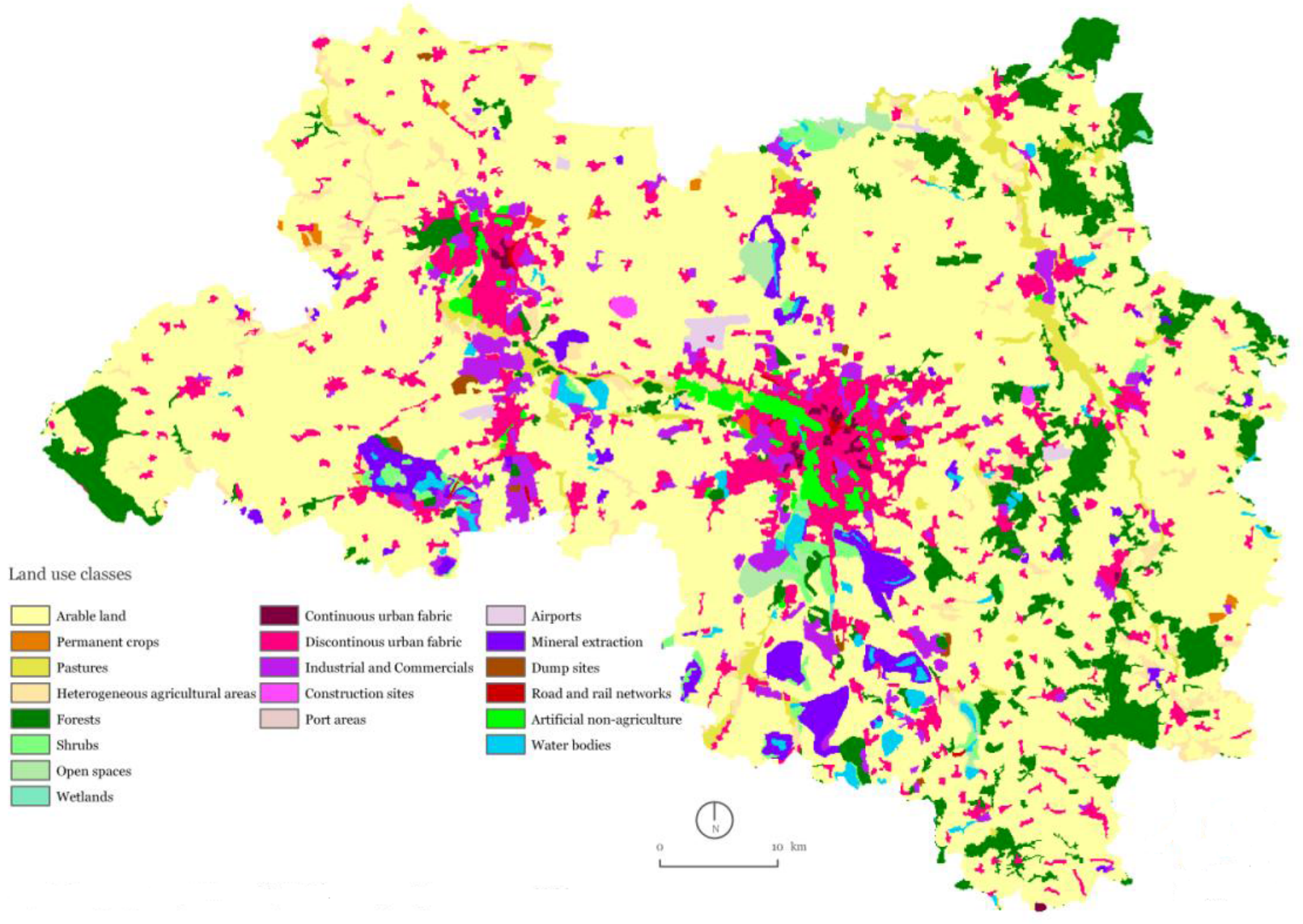

Figure 6. Leipzig 2025: Transport Scenario.

which would contribute to a reduction in commuting distances. In 2025, tourism, service and manufacturing sectors will have an impact on land-use dynamics, making industrial and commercial areas and construction sites grow by $68 \%$ and $208 \%$, respectively (Figure 7 ). Due to the compact pattern of urban development in this sce- nario, reductions in pastures (17\%), heterogeneous agricultural areas $(10.8 \%)$ and arable land $(0.6 \%)$ are lower compared to those in the H-TS (Figure 7). Among key transportation investments, there are fast railways to Munich, Berlin and Erfurt, which will serve public transportation from areas surrounding the Leipzig-Halle Re- 


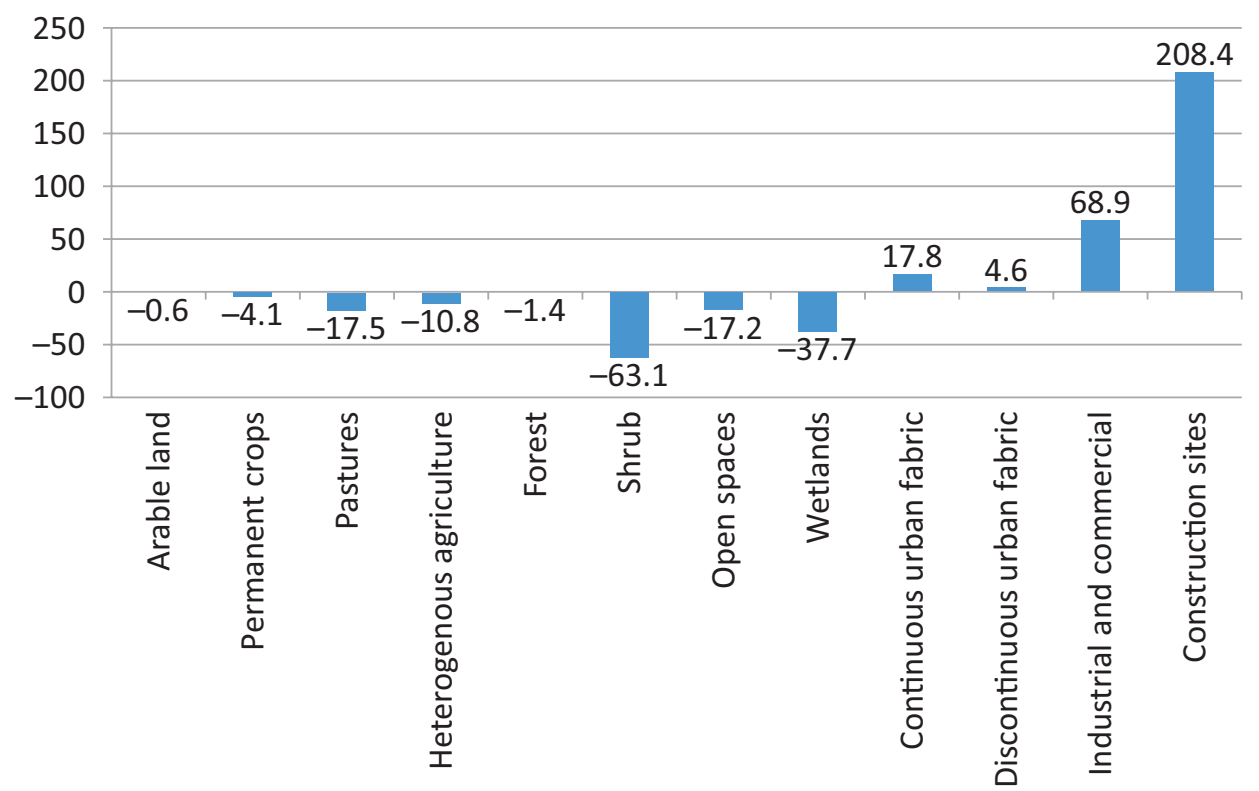

Figure 7. Percentage change of land-use classes in Transport Scenario (2000-2025).

gion. Therefore, mixed-use development could be more intense both in the inner city and along the transport corridors considering that mixed-use developments are supported by both planning policy and required transportation networks. This implies that the inner city of Leipzig will attract more population from the suburban areas and countryside thanks to the increasing investments in brownfield sites adjacent to the inner city.

These two scenarios show that transport accessibility has a stronger impact on land development patterns (i.e. dispersed or compact development) compared to the impact of economic trends. And, despite the strong investment in high-tech sectors in $\mathrm{H}-\mathrm{TS}$, this scenario leads to dispersed development due to poor transport accessibility.

\subsection{Evaluation Methodology: Impact Assessment of Transport-Land-Use Relationship in the Leipzig-Halle Region}

There are both direct and indirect effects of transportation provision on the land development processes. Directly, it determines the land devoted to transport facilities (such as roads, rail tracks, parking areas); while indirectly, it affects accessibility and development costs of various locations (lacono, Levinson, \& El-Geneidy, 2008; Litman, 2016). It is well documented in planning literature that automobile-oriented planning policies tend to increase urban sprawl by improving accessibility to urban fringe locations and by increasing the amount of land required for development. By contrast, policies supporting public transportation and pedestrian activities encourage more compact and mixed developments (Litman, 2016; Simmonds \& Coombe, 2013). It has been argued that rapid rail systems can play a critical role in overcoming problems posed by dispersed or sprawl type development patterns, especially when transport infrastructure investments are associated with supportive policies and land development plans (Litman, 2016; May, 2013). Among the competing transit technologies such as rapid rail, light rail, and express bus, these alternative options can provide high quality service in terms of reliability, speed, safety, reduced travel time and-with a greater probability - act as a substitute for private car usage. As a consequence, rapid rail systems have become a preferred policy approach to avoid road congestion and other detrimental effects of urban sprawl (Higgins, Ferguson, \& Kanaroglou, 2014; May, 2013). This constructs a framework for the current study focusing on sustainability impact assessment of high-speed rail provisions on land-use, in line with the tendency of compact development in TS presented in Table 4.

A wide variety of studies deal with the evaluation of transportation impacts on land-use, land development and environment (Bohman \& Nilsson, 2016; Dröes \& Rietveld, 2015), on certain externalities (i.e. accessibility, adjacent property values, etc.) and performed detailed analysis related to this area (Karou \& Hull, 2014; Zondag, de Bok, Geurs, \& Molenwijk, 2015 among others). However, there are few studies incorporating all of the possible externalities into their analysis. International literature on the inclusion of different impacts in evaluation process and transport appraisal methods in use for different countries can be found in Bristow and Nellthorp (2000) or Odgaard, Kelly and Laird (2005). Litman (2016) points out some of the weaknesses of current project evaluations and suggests using a more comprehensive approach for evaluating land-use impacts of transportation provisions. The literature shares a number of common impacts and indicators that are more or less similar to each other despite the existence of differences in their policy evaluation goals and appraisal method- 
Table 4. Characteristics of urban development scenarios in the Leipzig-Halle Region.

\begin{tabular}{|c|c|c|}
\hline & Hyper-Tech Scenario (H-TS) & Transport Scenario (TS) \\
\hline Population & $\begin{array}{l}\text { Population growth: } \\
\text { - Rapid increase of young population } \\
\text { - Increased fertility rates }\end{array}$ & $\begin{array}{l}\text { Population growth: } \\
\text { - In-migration of young population }\end{array}$ \\
\hline $\begin{array}{l}\text { Economic } \\
\text { Trends }\end{array}$ & $\begin{array}{l}\text { - Rapid increase in GDP } \\
\text { - Invest more in: high tech sectors (electronics, } \\
\text { computers, pharmaceuticals) } \\
\text { - More research institutes are encouraged in } \\
\text { science and research } \\
\text { - Tourism and service sectors as current trends } \\
\text { - Agriculture is of minor importance }\end{array}$ & $\begin{array}{l}\text { Rapid increase in GDP } \\
\text { - The industrial activity is strongly reinforced as } \\
\text { well as tourism, manufacturing and service } \\
\text { sectors strongly encouraged (e.g. public } \\
\text { services, health care, accommodation, food } \\
\text { and beverage, entertainment) } \\
\text { - More employment in science and research } \\
\text { - Agriculture also here is of minor importance }\end{array}$ \\
\hline $\begin{array}{l}\text { Spatial } \\
\text { Development/ } \\
\text { Planning }\end{array}$ & $\begin{array}{l}\text { - New industrial developments occur between } \\
\text { Leipzig-Halle axis and other towns } \\
\text { - New residential developments are encouraged } \\
\text { in the polycentric urban form }\end{array}$ & $\begin{array}{l}\text { - Increases in infrastructure construction (e.g. } \\
\text { demolished houses inside of the city replaced } \\
\text { by new housing, sports and recreational } \\
\text { activities) } \\
\text { - Existing old buildings are preserved or } \\
\text { demolished leading to perforation }\end{array}$ \\
\hline Transport & $\begin{array}{l}\text { - New transport investment (e.g. improvement } \\
\text { of national roads and better links to the } \\
\text { motorways; airport extensions) }\end{array}$ & $\begin{array}{l}\text { - Low investment in transportation due to high } \\
\text { fuel costs and environmental concerns } \\
\text { - Investment in local rapid transit systems } \\
\text { - Investment in fast railways to Munich, Berlin } \\
\text { and Erfurt (ICE) }\end{array}$ \\
\hline Overall Trends & $\begin{array}{l}\text { - Rapid technology advance-economic growth } \\
\text { - Low environmental protection } \\
\text { - Passive management leading to } \\
\text { peri-urbanisation and 'metro-polisation' of } \\
\text { rural area }\end{array}$ & $\begin{array}{l}\text { - Economic growth } \\
\text { - Moderate environmental intervention } \\
\text { - High energy prices affect transport costs } \\
\text { limiting commuting distances }\end{array}$ \\
\hline
\end{tabular}

ologies. Given the literature, the main steps in the evaluation of transportation-land-use relationship are summarised in Table 5.

It is obvious from Table 5 that transportation provision has significant impacts on land-use, and as empirical evidence has shown, it is not so easy to quantify in detail most of these impacts. Some of the impacts and indicators can be represented in monetary values, while others can be expressed in a more qualitative or quantitative way. Here, an important issue to consider is the correlation among various indicators, such as the positive correlation between land-use accessibility and land values, or the negative correlation between air pollution exposure and area property values. Considering the correlation effects, impacts and indicators should be kept as orthogonal as possible to prevent double counting problems in the transport policy evaluations.

The impacts of high-speed rail investments on land development in the Leipzig-Halle Region will be evaluated through the selection of related indicators considering four main types:

1. Direct Impacts of Transport Provision on LandUse: costs and capital investments of transport infrastructure constitute a significant part in project evaluations, and therefore, they are incorporated in all transport evaluation studies (European Commission, 2008; Odgaard et al., 2005). Further impact of transport investment is on the total amount of green land used for transport facilities. The problem is related to the depletion of green areas on or around newly provided transportation axis.

2. Impacts on Development Patterns: compact developments are more likely to be associated with lesser consumption of green land of high natural and agricultural value compared to more dispersed developments (Wheeler, 2013). This is related to a requirement of less space for transport and urban facilities as such facilities are closely located in the compact form. Dispersed development needs to provide public services to the low-density population, with reflected increases in infrastructure and public service costs (Litman, 2016). Álvarez, Prieto and Zofio (2014) have shown that municipal costs of residential public service provision of water distribution, sewage collection and cleansing of wastewater increase considerably with dispersed development.

3. Impacts on Land-Use Accessibility: transport infrastructure investments contribute to economic 
Table 5. Impacts of transportation provision on land-use and suggested indicators for the current study. QT: quantitative assessment, QL: qualitative assessment. Adapted from Litman (2016).

\begin{tabular}{|c|c|c|c|}
\hline $\begin{array}{l}\text { Transport } \\
\text { provision } \\
\text { results in* }\end{array}$ & Physical Effects* & Impacts* & $\begin{array}{l}\text { Suggested Indicators for the Current } \\
\text { Study }\end{array}$ \\
\hline $\begin{array}{l}\text { Direct changes } \\
\text { in land-use }\end{array}$ & $\begin{array}{l}\text { Amount of land } \\
\text { devoted for } \\
\text { transportation } \\
\text { facilities }\end{array}$ & $\begin{array}{l}\text { 1. Green space preservation } \\
\text { 2. Transportation facility land values } \\
\text { 3. Development costs/capital } \\
\text { investments } \\
\text { 4. Adjacent property values }\end{array}$ & $\begin{array}{l}\text { Changes in: } \\
\text { - Development costs/capital } \\
\text { investments of transportation } \\
\text { infrastructure (QT) } \\
\text { - Total green area used for transport } \\
\text { facilities (QT) }\end{array}$ \\
\hline $\begin{array}{l}\text { Changes in } \\
\text { development } \\
\text { patterns }\end{array}$ & $\begin{array}{c}\text { Location, } \\
\text { density and } \\
\text { compactness of } \\
\text { development } \\
\end{array}$ & $\begin{array}{l}\text { 5. Green space preservation } \\
\text { 6. Public service costs }\end{array}$ & $\begin{array}{l}\text { Changes in: } \\
\text { - Total green area (QT; QL) } \\
\text { - Costs of providing public services (QL) }\end{array}$ \\
\hline $\begin{array}{l}\text { Changes in } \\
\text { land-use } \\
\text { accessibility } \\
\text { and transport } \\
\text { diversity }\end{array}$ & $\begin{array}{l}\text { Dispersion of } \\
\text { common } \\
\text { destinations, } \\
\text { and quality of } \\
\text { travel options }\end{array}$ & $\begin{array}{l}\text { 7. Changes in per capita vehicle travel } \\
\text { 8. Area property values } \\
\text { 9. Socio-economic benefits } \\
\text { a. Affordability (housing) } \\
\text { b. Affordability (transport) } \\
\text { c. Social Inclusion } \\
\text { d. Socio-economic growth } \\
\text { 10. Land-use/transportation } \\
\text { accessibility } \\
\text { 11. Transport network effects }\end{array}$ & $\begin{array}{l}\text { Changes in: } \\
\text { - Travel time on proposed rail system (QT) } \\
\text { - Passenger vehicle kms (car, train, air, } \\
\text { slow modes of transport) (QT) } \\
\text { - Number of passengers (car, train, air, } \\
\text { slow modes of transport) (QT) } \\
\text { - Accident costs (QT) } \\
\text { - Traffic congestion (QL) } \\
\text { - Transport diversity/integration (QL) } \\
\text { - Land-use-transport accessibility (QT) }\end{array}$ \\
\hline $\begin{array}{l}\text { Changes in } \\
\text { travel activity }\end{array}$ & $\begin{array}{l}\text { Per capita } \\
\text { motor vehicle } \\
\text { ownership and } \\
\text { use }\end{array}$ & $\begin{array}{l}\text { 12. Consumer transport costs } \\
\text { 13. Accidents } \\
\text { 14. Energy and environmental impacts } \\
\text { a. Energy consumption } \\
\text { b. Air/noise pollution exposure } \\
\text { c. Climate change } \\
\text { d. Water resources } \\
\text { e. Landscape and heritage } \\
\text { f. Ecological impacts } \\
\text { g. Vibration } \\
\text { h. Waste disposal }\end{array}$ & $\begin{array}{l}\text { Changes in: } \\
\text { - Climate change emissions }\left(\mathrm{CO}_{2}\right)(Q T) \\
\text { - Noise pollution (QL) } \\
\text { - Water pollution (QL) } \\
\text { - Vibration (QL) } \\
\text { - Ecological impacts (QL) } \\
\text { - Accessibility to heritage sites and } \\
\text { landscape (QL) }\end{array}$ \\
\hline
\end{tabular}

growth by expanding the stock of capital, increasing labour productivity and therefore ensuring more efficient production (Pereira \& Andraz, 2013). The general argument in the literature is that the benefits from transport improvements are mainly represented in travel cost savings, which result from improvements in the efficiency of the transportation system. Travel cost savings include the savings in travel times, vehicle operation costs and costs of accidents, reduction in traffic congestion, etc. (Litman, 2016). Savings in travel time capture economic growth effectsstemming from travel time savings of labour and traffic congestion effects-reflecting the ease of travelling with a considerable shift from private car use to rail-transit based transportation. This also includes accessibility changes in land-useindicating savings in various travel costs and the resultant easiness of access-reflecting the shift from dispersed developments to more compact ur- ban form (Simmonds \& Coombe, 2013). Concerning travel time, two different indicators are suggested in the current study: an indicator of travelling time on the proposed rail system, and an indicator of potential passenger accessibility for different modes of transport (i.e. car, train, air).

Regarding accident costs, it is widely accepted that public modes of transport have lower accident rates than private car trips (Litman, 2000, 2016). Among the alternative public transport modes, high-speed rail systems can be considered as the most reliable ones due to the low likelihood of fatal accident occurrence. Therefore, a shift from car-based transportation to rail-based systems can contribute to considerable savings in (fatal, serious injury and minor injury) accident costs. Accident cost savings can also be considered as socioeconomic benefits which contribute to social and economic well-being by reducing injury and fatality rates and the resultant losses in labour force. 
Vehicle operating cost savings are associated with user benefits indicating the shift of travel from private car to public transit such as local rapid transit systems and high-speed rail. At the very least, the shift from private car to rail-based systems saves fuel and oil, which can be considered to have important impacts on energy consumption and environment pollution levels (May, 2013). In addition, there are costs of depreciation, insurance and parking which are associated with increasing car use which lead to increases in repair and maintenance costs, reductions in vehicle resale value, increases in parking and traffic costs, etc. (Litman, 2000, 2016). Concerning vehicle operating costs, an indicator of total vehicle kilometres per year for different modes of transport (i.e. car, rail, air and slow modes) will be evaluated.

4. Impacts on Travel Activity: related to energy and environmental factors, we can state that dramatic change in the climate system is resulting from the human-induced emissions i.e. greenhouse gas emissions (GHG) such as carbon dioxide $\left(\mathrm{CO}_{2}\right)$, methane $\left(\mathrm{CH}_{4}\right)$ and nitrous oxide $\left(\mathrm{N}_{2} \mathrm{O}\right)$. Although transportation is not the only contributor to the rising levels of GHG, it is the fastest rising contributor to the problem (European Commission, 2007). Dramatic increase in private vehicle ownershipwhich is also encouraged by the provision of largescale urban motorways - has led to air and noise pollution and increasing amounts of transportrelated energy consumption. Although there are examples of counter arguments, the general research has been in favour of compact urban form in comparison to the more dispersed urban developments largely on the grounds of transportation energy savings (Breheny, 1995; May, 2013). In addition, energy and environmental impacts i.e. air/noise pollution exposure, vibration, climate change emissions (greenhouse gas emissions), water pollution, ecological impacts, landscape and heritage are all important for the impact assessment of transportation infrastructure investments.

\subsection{Transport Related Indicators}

In this study, the transportation-related indicators refer to: $\mathrm{CO}_{2}$ emissions, total passenger kilometres, total number of passengers, and potential passenger accessibil- ity by different modes of transport. They were obtained from the future simulations of the ASTRA-EC Model that has been developed as part of the ASSIST project of the European Commission of the 7th Framework Programme $^{3}$. The details of the ASTRA-EC Model are provided in Fermi et al. (2014). The Model was first simulated for the baseline scenario where there is investment on Trans European Network-Transport (TEN-T) projects comprising the Leipzig/Halle-Erfurt high-speed rail section. It is important to note that all these projects had already been approved by the EC, and therefore the baseline scenario considers all the TEN-T projects by keeping constant all other parameters related to economy, society, environment and transportation (see Fermi et al., 2014). The Model was also simulated for the alternative scenario where there is accelerated investment on TEN-T projects, improvements in frequency and reliability of bus and train services, introduction of urban road user charges related to limited entrance of road transport vehicles to urban areas, charging of heavy-duty vehicles for the use of the motorway, new vehicle taxations based on $\mathrm{CO}_{2}$ emissions and restrictive limits of $\mathrm{CO}_{2}$ and other emissions on new vehicle purchasing. In the alternative scenario, there are settings of parameters to ensure transport system reliability and environmental protection. The accelerated construction of TEN-T projects, in particular rail investments, will improve accessibility of the urban locations, and can support mixed-use developments when associated with supportive land-use plans and policies. Therefore, estimates from the alternative scenario are linked to the TS of compact development and estimates from the baseline scenario are considered for the H-TS of dispersed development as provided in Table 4.

\section{Findings}

To evaluate the sustainability of transport-land-use relationships in the Leipzig-Halle Region, the selected impacts and indicators in Table 5 are subject to quantitative and qualitative assessment regarding dispersed and compact development scenarios (Table 4). The indicators that are subject to quantitative assessment are given in Table 6. For example, the table shows that there are costs of new transport infrastructure provisions of more than 2 billion euros in the TS. Among the new rail investment projects concerning the Leipzig/Halle-Erfurt line, there is a 2-km railway tunnel connecting Leipzig Main and Leipzig Bavarian stations, aiming at improving

\footnotetext{
${ }^{3}$ ASTRA-EC Model is developed in Vensim, which is also linked with other existing tools developed by the EC (i.e. TRANS-TOOLS and POLES models). The model covers the time period from 1995 till 2050, and covers all EU27 member states plus Norway and Switzerland. The population module of the Model simulates demographic development for the European countries covered in the model, comprising information on age structure, gender, household type and income group. The population module provides valuable information to the transport module considering that the differentiation of population according to the specific attributes allow different mobility patterns and elasticity to be considered in the Model. The economic module consists of inputs such as interactions between economic sectors, demand-supply interactions and employment. The transport module consists of classical 4-step transportation model both for passenger and freight transport. The model adjusts the estimation of trip generation, distribution and modal split phases on the basis of parameters differentiated by demand segments. The vehicle fleet module simulates the development of stock of road vehicles in terms of size and composition. The common structure for road vehicles is characterised by a feedback between annual new vehicle purchases, the number of vehicles in the stock, the scrapping of vehicles per year and a generated demand regulating the change of vehicle fleets (for details see Fermi et al., 2014).
} 
functional integration of the two core cities. Although Leipzig and Halle are well connected to each other by means of road and rail transportation, the functional integration of the two cities is poor given that there is relatively less traffic congestion between the two cities even in the rush hours (see European Metropolitan Network Institute [EMI], 2012). The new tunnel improves 'the accessibility of Leipzig by rail and provides better connections between Leipzig and Halle with Chemnitz and Zwickau' (EMI, 2012, p. 12). In Table 6, we also note that total land area required for new rail construction is 370 hectares covering the catchment area of the new rail along the Leipzig/Halle-Erfurt corridor. There will be lost 160 hectares of green land along the catchment area (expanded from Leipzig/Halle to the city of Erfurt) that are required for the construction of the new rail track.

From Table 6, H-TS of dispersed development shows an increase in total area of discontinuous urban fabric compared to the observed in TS, which would result in higher public service provision costs in the case of the former scenario. Compact development in TS is associated with larger total areas of green land than those in $\mathrm{H}-\mathrm{TS}$, implying more protection of highly valued agricultural land and natural areas in the case of TS. Total area of open spaces is also higher in TS, implying the benefits of less space consumption of urban facilities in the compact form, supporting the preservation of green land and open spaces.

We note that there are considerable travel time savings on the proposed rail lines, which is important for the German Government aim to achieve considerable shifts from road and air transport to the newly constructed rail system. Travel time savings on the rail network will induce shifts particularly from private modes of transport, achieving travel time savings on the road network. The results show that the total number of passengers and passenger kilometres of private vehicle transportation is higher in the H-TS of dispersed development compared to TS. By contrast, these parameters show lower values regarding train, air and slow modes of transportation in the H-TS compared to those obtained for compact development cases in TS. Larger private vehicle kilometres in the dispersed development scenario are associated with higher costs of vehicle operations and environmental pollution compared to the lower estimates in the compact development scenario. In fact, the dispersed development scenario is characterised by higher $\mathrm{CO}_{2}$ emissions, higher road-based traffic accidents, lower passenger accessibility to public transport services, and lower number of passengers using slow modes of transport such as walking and cycling (Table 6). These findings suggest the sustainability of transportation-land-use relationship is more evident in the transport scenario given that compact development is more efficient when the socioeconomic and environmental impacts are considered.

Considering the difficulties involved in quantifying all the impacts and indicators specified in Table 5, a qualitative assessment framework is provided for the se- lected impacts, as these cannot be quantified based on data accessibility issues. The details of qualitative assessments focusing on transport-related impacts, land development and environmental impacts are explained in Table 7 . It is important to note that the qualitative evaluation framework presented in the table is subjective and it can be used to complement the outcomes of quantitative assessments. Therefore, we suggest that future studies should focus on developing new data sources and research primarily on the quantification of environmental and transport-related indicators that were not quantified in the current study.

\section{Conclusion}

This paper examined the sustainability implications of transportation and land-use relationship through focusing on the key linkages and impacts of transportation infrastructure investments on land development trends in the Leipzig-Halle Region. Innovative aspects of this study are that the expected cost of infrastructure investment options can be compared with detailed quantitative data on some of the expected environmental and social variations in impacts which can be expected in alternative scenarios. This includes impacts on land-use, passenger numbers, travel costs and the impact on the environment by $\mathrm{CO}_{2}$ emissions.

From the quantitative and qualitative assessments of impacts and indicators on social, economic and environmental considerations, our findings provide evidencebased assessments of compact urban structures and concentrated development patterns with data supporting conclusions that compact scenarios of urban development will prove more efficient in terms of the sustainability impacts on urban form and transport use patterns. Unlike the compact development case, dispersed or sprawled development as in the case of H-TS is costlier over the long term, regarding the negative impacts on the environment and social welfare. Transportrelated benefits of compact urban development could be achieved through the application of policies and plans supporting sustainability of transportation and land-use relationships in the compact urban form. The identification and prioritisation of two evidence-based land development scenarios in our research and impact assessment processes can be used as a policy support tool in discussions of alternative development and investment decisions such as compact and dispersed developments in Leipzig-Halle and other case study areas.

Leipzig is an example of a post-socialist city, which had experienced a shrinkage process in 1990s and followed by modest population growth in the last two decades. As the MOLAND Model was successfully applied to a declining region for the first time, this provides the opportunity for the cross-comparison of the presented methodology and research findings regarding the transport impact assessment of compact and dispersed development scenarios with other case study re- 
Table 6. Quantitative assessment of selected indicators for the dispersed and compact development scenarios in the Leipzig-Halle Region. Dissavings are shown in parentheses with a negative sign. By slow modes of transportation, we refer to walking and cycling.

\begin{tabular}{|c|c|c|c|c|}
\hline Indicator & $\begin{array}{l}\text { Scenario } \\
1 \text { (H-TS) }\end{array}$ & $\begin{array}{l}\text { Scenario } \\
2 \text { (TS) }\end{array}$ & $\begin{array}{c}\text { Savings } \\
\text { (Dissavings) } \\
\text { in Scenario } 2 \\
\text { vs. Scenario } 1 \\
\end{array}$ & Explanation \\
\hline \multicolumn{5}{|c|}{ Direct Impacts of Transport Investment } \\
\hline $\begin{array}{l}\text { Investment costs of new line } \\
\text { Erfurt-Leipzig/Halle (million } \\
\text { Euros) }\end{array}$ & 0 & 2,310 & $(-)$ & \multirow{4}{*}{$\begin{array}{l}\text { Source: Federal Ministry of } \\
\text { Transport, Building and } \\
\text { Housing, 2003. }\end{array}$} \\
\hline $\begin{array}{l}\text { Investment costs of } \\
\text { upgrading Leipzig-Dresden } \\
\text { line (million Euros) }\end{array}$ & 929.1 & 929.1 & 0 & \\
\hline $\begin{array}{l}\text { Investment costs of } \\
\text { upgrading }\end{array}$ & & & & \\
\hline $\begin{array}{l}\text { Karlsruhe-Stuttgart- } \\
\text { Nuremberg-Leipzig/Dresden } \\
\text { line (million Euros) }\end{array}$ & 1,499 & 1,499 & 0 & \\
\hline $\begin{array}{l}\text { Total land area along } \\
\text { Leipzig/Halle-Erfurt corridor } \\
\text { required for newly provided } \\
\text { transport infrastructure }(\mathrm{Ha})\end{array}$ & 0 & 370 & $(-)$ & $\begin{array}{l}\text { The total area required for new } \\
\text { rail line is } 370 \text { hectares, of } \\
\text { which } 160 \text { hectares is for the } \\
\text { rail track along the } \\
\text { Leipzig/Halle-Erfurt corridor } \\
\text { (Schubert \& Kniestedt, 1994). }\end{array}$ \\
\hline \multicolumn{5}{|c|}{ Impacts on Development Patterns } \\
\hline $\begin{array}{l}\text { Total area of discontinuous } \\
\text { urban fabric }\left(\mathrm{km}^{2}\right)\end{array}$ & 411.2 & 377.4 & + & \multirow{4}{*}{$\begin{array}{l}\text { These are the results from } \\
\text { scenario runs of the MOLAND } \\
\text { Model for the year } 2025 \\
\text { (Lavalle et al., 2009) }\end{array}$} \\
\hline $\begin{array}{l}\text { Total area of agricultural land } \\
\left(\mathrm{km}^{2}\right)\end{array}$ & 3,517 & 5,193 & + & \\
\hline $\begin{array}{l}\text { Total area of semi-natural } \\
\text { vegetation and wetlands } \\
\left(\mathrm{km}^{2}\right)\end{array}$ & 38.02 & 78.05 & + & \\
\hline $\begin{array}{l}\text { Total area of open spaces } \\
\left(\mathrm{km}^{2}\right)\end{array}$ & 27.8 & 43.2 & + & \\
\hline
\end{tabular}

\section{Impacts on Land-Use Accessibility and Transport Diversity}

Travel time on proposed rail

section (Leipzig-Erfurt line)

$\begin{array}{lll}72 & 44\end{array}$

$72 \quad 44+$

(min.)

Travel time on proposed rail

section (Halle-Erfurt line)

(min.)

77

34

Source: DB Netze (2015)

Travel time on proposed rail

section

(Berlin-Halle-Erfurt-Frankfurt

297

233

line) (min.)

Number of fatality

accidents/year (car)

91.24

76.25

$5,639.8$
Number of injury accidents/year (car)
These numbers were calculated from forecasts of fatality and injury accidents in Germany developed in TEN-STAC project, representing the forecasted numbers of accidents in the Leipzig Region in 2020 (see TEN-STAC, 2004)

$4,713.3+$


Table 6. Quantitative assessment of selected indicators for the dispersed and compact development scenarios in the Leipzig-Halle Region. Dissavings are shown in parentheses with a negative sign. By slow modes of transportation, we refer to walking and cycling. (Cont.)

\begin{tabular}{|c|c|c|c|c|}
\hline Indicator & $\begin{array}{c}\text { Scenario } \\
1 \text { (H-TS) }\end{array}$ & $\begin{array}{l}\text { Scenario } \\
2 \text { (TS) }\end{array}$ & $\begin{array}{c}\text { Savings } \\
\text { (Dissavings) } \\
\text { in Scenario } 2 \\
\text { vs. Scenario } 1 \\
\end{array}$ & Explanation \\
\hline \multicolumn{5}{|c|}{ Impacts on Land-Use Accessibility and Transport Diversity } \\
\hline $\begin{array}{l}\text { Potential passenger } \\
\text { accessibility (car) }\end{array}$ & 7,989 & 4,661 & + & \multirow{11}{*}{$\begin{array}{l}\text { These are the transport } \\
\text { indicators developed from the } \\
\text { transport module of the } \\
\text { ASTRA-EC Model runs for the } \\
\text { year } 2025 \text { for the TEN-T } \\
\text { (Trans-European } \\
\text { Network-Transport) } \\
\text { infrastructure investments as } \\
\text { part of the ASSIST project of } \\
\text { the EC. The indicators } \\
\text { represent the regional values } \\
\text { (NUTS } 2 \text { regional value for } \\
\text { Leipzig) in the cases of baseline } \\
\text { dispersed development and } \\
\text { compact development } \\
\text { scenarios (see ASSIST, 2011) }\end{array}$} \\
\hline $\begin{array}{l}\text { Potential passenger } \\
\text { accessibility (train) }\end{array}$ & $1,955.9$ & 2,032 & + & \\
\hline $\begin{array}{l}\text { Potential passenger } \\
\text { accessibility (air) }\end{array}$ & $1,907.3$ & $2,215.2$ & + & \\
\hline $\begin{array}{l}\text { Total passenger kms } \\
\text { (mil.)/year (car) } \\
\end{array}$ & 12,533 & 10,474 & + & \\
\hline $\begin{array}{l}\text { Total passenger kms } \\
\text { (mil.)/year (train) }\end{array}$ & $1,999.5$ & $3,937.5$ & + & \\
\hline $\begin{array}{l}\text { Total passenger kms } \\
\text { (mil.)/year (air) }\end{array}$ & 643.2 & 1,113.5 & + & \\
\hline $\begin{array}{l}\text { Total passenger kms } \\
\text { (mil.)/year (slow modes) }\end{array}$ & $1,191.5$ & $1,296.6$ & + & \\
\hline $\begin{array}{l}\text { Total number of passengers } \\
\text { (mil.)/year (car) }\end{array}$ & 629.7 & 551.5 & + & \\
\hline $\begin{array}{l}\text { Total number of passengers } \\
\text { (mil.)/year (train) }\end{array}$ & 140.8 & 166.9 & + & \\
\hline $\begin{array}{l}\text { Total number of passengers } \\
\text { (mil.)/year (air) }\end{array}$ & 0.95 & 2.03 & + & \\
\hline $\begin{array}{l}\text { Total number of passengers/ } \\
\text { (mil.) year (slow modes) }\end{array}$ & 438.1 & 476.7 & + & \\
\hline \multicolumn{5}{|l|}{ Impacts on Travel Activity } \\
\hline $\mathrm{CO}_{2}$ emissions (mil. kg/year) & $1,492.9$ & $1,212.5$ & + & \\
\hline
\end{tabular}

Table 7. Qualitative assessment of selected impacts and indicators for the Leipzig-Halle Region.

\begin{tabular}{|c|c|c|c|}
\hline Impacts & Evaluation Criteria & Details & $\begin{array}{c}\text { Expected Impact of } \\
\text { New Rail } \\
\text { Investment in } \\
\text { Leipzig-Halle Region }\end{array}$ \\
\hline $\begin{array}{l}\text { Landscape \& } \\
\text { environment }\end{array}$ & $\begin{array}{l}\text { Environmental Risk } \\
\text { Assessment (ERA) } \\
\text { and Habitats } \\
\text { Directive } \\
\text { Assessment (HDA) }\end{array}$ & $\begin{array}{l}\text { Among the alternative route options, the selected route } \\
\text { of Leipzig-Halle-Erfurt line has the lowest land-take and } \\
\text { has lower or equal environmental impacts compared to } \\
\text { other route options (Feldwisch, Drescher, Flügel, \& Lies, } \\
\text { 2007). There are new constructions of viaducts, tunnels } \\
\text { and bridges on the selected rail line. The required } \\
\text { environmental assessments and legal actions were } \\
\text { carried out for the construction of engineering } \\
\text { structures including particularly the longest bridge of } \\
\text { Germany. There are environmental issues to be } \\
\text { considered are the Habitats Directive, the zone being a } \\
\text { bird sanctuary and a drinking water protection zone } \\
\text { grade III, and the Saale-Elster viaduct crossing the } \\
\text { floodplains of Saale and White Elster. The line towards } \\
\text { Leipzig follows a course of no major structures. } \\
\text { Measures were taken to reduce interference with } \\
\text { the ecosystem. }\end{array}$ & $\begin{array}{c}\text { No significant impact } \\
\text { due to mitigation } \\
\text { measures }\end{array}$ \\
\hline
\end{tabular}


Table 7. Qualitative assessment of selected impacts and indicators for the Leipzig-Halle Region. (Cont.)

\begin{tabular}{|c|c|c|c|}
\hline Impacts & Evaluation Criteria & Details & $\begin{array}{c}\text { Expected Impact of } \\
\text { New Rail } \\
\text { Investment in } \\
\text { Leipzig-Halle Region }\end{array}$ \\
\hline Heritage sites & $\begin{array}{l}\text { New rail increases } \\
\text { accessibility to the } \\
\text { heritage sites and } \\
\text { leads to discovery of } \\
\text { new heritage sites } \\
\text { during construction } \\
\text { works }\end{array}$ & $\begin{array}{l}\text { Following archaeological excavations in the } \\
\text { construction zone in the Querfurt area, artifacts and } \\
\text { remains from the Bronze age and finds of more than } \\
7500 \text { years were uncovered. The most important pieces } \\
\text { are exhibited in the museum in Halle. The rail connects } \\
\text { to the other historical sites and new findings on the } \\
\text { route southern to Erfurt. }\end{array}$ & Positive impact \\
\hline $\begin{array}{l}\text { Ecological } \\
\text { impacts }\end{array}$ & $\begin{array}{l}\text { New rail transport } \\
\text { infrastructure and } \\
\text { operation impacts } \\
\text { on flora, fauna and } \\
\text { their habitat }\end{array}$ & $\begin{array}{l}\text { Flora and fauna were subject to examination prior to } \\
\text { the rail construction works in order to prevent } \\
\text { disturbance to the ecosystem services. This includes } \\
\text { re-homing of sand lizards and bats in previously } \\
\text { prepared replacement habitat during construction } \\
\text { works. They will be returned to their original habitats } \\
\text { after the end of construction work. Along the newly } \\
\text { constructed rail corridor, conservation measures have } \\
\text { been introduced to compensate for damage or } \\
\text { replacement of lost values (new hedges and trees will } \\
\text { be planted, mountain pastures will be nurtured etc.). }\end{array}$ & $\begin{array}{l}\text { No significant impact } \\
\text { due to mitigation } \\
\text { measures and } \\
\text { compensation of the } \\
\text { ecosystem services } \\
\text { of negatively } \\
\text { influenced areas } \\
\text { (following } \\
\text { construction work) } \\
\text { in other locations }\end{array}$ \\
\hline Noise & $\begin{array}{l}\text { New and existing } \\
\text { transport system has } \\
\text { impact on the } \\
\text { environment } \\
\text { through generation } \\
\text { of noise pollution }\end{array}$ & $\begin{array}{l}\text { Considering the expected shifts from road to rail } \\
\text { transportation, there will be reduction in the number of } \\
\text { road vehicles. This will induce reduction in the noise } \\
\text { levels stemming from road transportation. There are } \\
\text { tunnels and other structures constructed for the use of } \\
\text { new high-speed rail. These structures are constructed } \\
\text { with the systems allowing the most modern noise } \\
\text { protection. There are walls, soundproof windows and } \\
\text { barriers to reduce noise pollution for the residents. }\end{array}$ & $\begin{array}{l}\text { Reduction in noise } \\
\text { pollution }\end{array}$ \\
\hline Vibration & $\begin{array}{l}\text { The increase in train } \\
\text { speeds, axle loads } \\
\text { and traffic volumes } \\
\text { on current train lines } \\
\text { lead to increases in } \\
\text { vibration to which } \\
\text { the surroundings are } \\
\text { subjected. }\end{array}$ & $\begin{array}{l}\text { The effects of sound and vibrations were analysed along } \\
\text { the newly constructed rail line (Leipzig/Halle-Erfurt line) }\end{array}$ & $\begin{array}{l}\text { Adverse effects may } \\
\text { exist during the } \\
\text { construction works } \\
\text { along the catchment } \\
\text { of rail line }\end{array}$ \\
\hline Water & $\begin{array}{c}\text { Pollution associated } \\
\text { with transport } \\
\text { facilities and vehicle } \\
\text { use }\end{array}$ & $\begin{array}{l}\text { In order to prevent water pollution during rail } \\
\text { construction and operation, various measures have } \\
\text { been introduced including: drainage systems for all the } \\
\text { tracks and points affected; two new rail water retention } \\
\text { ponds be provided; modifications of existing drains and } \\
\text { ditches to the new track; all the water collected will be } \\
\text { soaked to the construction site. }\end{array}$ & $\begin{array}{c}\text { No significant impact } \\
\text { due to mitigation } \\
\text { measures }\end{array}$ \\
\hline $\begin{array}{l}\text { Transportation } \\
\text { diversity \& } \\
\text { integration }\end{array}$ & $\begin{array}{l}\text { New rail provides an } \\
\text { alternative option to } \\
\text { air and road } \\
\text { transportation and } \\
\text { integrates to the } \\
\text { existing transport } \\
\text { system }\end{array}$ & $\begin{array}{l}\text { Leipzig-Halle-Erfurt line connects Berlin to Nurnberg } \\
\text { and also connects to other cities from Erfurt (to } \\
\text { Frankfurt), Berlin (to Hamburg) and Nurnberg (to } \\
\text { Munchen and Verona). Erfurt, Halle and Leipzig } \\
\text { junctions are the central interchange stations of the } \\
\text { region. The connection of the city of Halle, Leipzig/Halle } \\
\text { Airport, the Leipzig Trade Fair and the freight centres in } \\
\text { Erfurt and Leipzig were considered. The line is } \\
\text { important for the European rail connection as it is part } \\
\text { of the Line } 1 \text { of Trans-European Transport Networks } \\
\text { (TEN-T) from Sicily to Scandinavia (TEN-STAC, 2004). }\end{array}$ & Positive impact \\
\hline
\end{tabular}


gions. This will assist policy formulation, decision making and reviews concerning the transport infrastructure investment policies and decisions in regions both in Europe and internationally.

\section{Acknowledgments}

This research presented here was undertaken in collaboration with PLUREL project partners and funded by PLUREL project: Peri-Urban Land-Use Relationships-Strategies and Sustainability Assessment Tools For Urban-Rural Linkages funded by the European Commission's Sixth Framework Programme for Research (EC FP6 036921).

\section{Conflict of Interests}

The authors declare no conflict of interests.

\section{References}

Alonso, W. (1964). Location and land use: Toward a general theory of land rent. Cambridge, MA: Harvard University Press.

Álvarez, I. C., Prieto, A. M., \& Zofio, J. L. (2014). Cost efficiency, urban patterns and population density when providing public infrastructure: A stochastic frontier approach. European Planning Studies, 22(6), 1235-1258.

ASSIST. (2011). The design of the ASTRA-ECModel (ASSIST deliverable D4.1). Karlsruhe, Germany: FraunhoferISI. Retrieved from http://assist-project.eu/assistproject-en/content/ deliverables.php

Barredo, J. I., Demicheli, L. (2003). Urban sustainability in developing countries' megacities: Modeling and predicting future urban growth in Lagos. Cities, 20(5), 297-310.

Barredo, J. I., Demicheli, L., Lavalle, C., Kasanko, M., \& McCormick, N. (2004). Modelling future urban scenarios in developing countries: An application case study in Lagos, Nigeria. Environment and Planning B, 31(1), 65-84.

Barredo, J. I., Kasanko, M., McCormick, N., \& Lavalle, C. (2003). Modelling dynamic spatial processes: Simulation of future scenarios through cellular automata. Landscape and Urban Planning, 64(3), 145-160.

Batty, M. (2008). The size, scale and shape of cities. Science, 319(5864), 769-771.

Berkner, A. (2000). The lignite industry and the reclamation of land-developments in the Rhenish, Central German and Lusatian mining areas since 1989. In A. Mayr \& W. Taubmann (Eds.), Germany ten years after reunification. Leipzig: Institut für Länderkunde.

Bertaud, A. (2004). The spatial organization of cities: Deliberate outcome or unforeseen consequence? (Working Paper 2004-01). Berkeley: Institute of Urban and Regional Development, University of California.

Bohman, H., \& Nilsson, D. (2016). The impact of regional commuter trains on property values: price seg- ments and income. Journal of Transport Geography, $56,102-109$.

Breheny, M. (1995). Compact cities and transport energy consumption. Transactions of the Institute of British Geographers, 20(1), 81-101.

Breheny, M. (2001). Densities and sustainable cities: The UK experience. In M. Eschenique \& A. Saint (Eds.) Cities for the new millennium. London: Spon Press.

Bristow, A. L., \& Nellthorp, J. (2000). Transport project appraisal in the European Union. Transport Policy, 7(1), 51-60.

Broitman, D., \& Czamanski, D. (2015). Burst and avalanches: the dynamics of polycentric urban evolution. Environment and Planning B, 42(1), 58-75.

Burton, E. (2013). The potential of the compact city for promoting social equity. In K. Williams, E. Burton, \& M. Jenks (Eds.), Achieving sustainable urban form. London: Spon Press.

DB Netze. (2015). Strecken Prospekt Neubaustrecke Erfurt-Leipzig/Halle. Retrieved from http://fahrweg. dbnetze.com/file/fahrweg-de/2394134/9Pz20C66xS _Pxtk1lcEk8XzeTvE/9837564/data/2015_33_Strecke nprospekt.pdf

Dröes, M. I., \& Rietveld, P. (2015). Rail-based public transport and urban spatial structure: The interplay between network design, congestion and urban form. Transportation Research Part B: Methodological, 81(2), 421-439.

European Commission (1999). European spatial development perspective: Towards balanced and sustainable development of the territory of the EU. Luxembourg: Office for Official Publications of the European Communities.

European Commission. (2007). Green paper-Towards a new culture for urban mobility. Brussels: European Commission.

European Commission. (2008). Guide to cost benefit analysis of investment projects. Luxembourg: Office for Official Publications of the European Communities.

European Environment Agency. (2002). Towards an urban atlas: Assessment of spatial data on 25 European cities and urban areas (Environmental Issue Report 30). Copenhagen: European Environment Agency.

European Environment Agency. (2006). Urban sprawl in Europe: The ignored challenge (EEA Report No: 10/2006). Luxembourg: Office for Official Publications of the European Communities.

European Metropolitan Network Institute. (2012). Case study Metropolregion Mitteldeutschland. The Hague: EMI.

Federal Ministry of Transport, Building and Housing. (2003) Federal transport infrastructure plan. Berlin: Federal Ministry of Transport, Building and Housing. Retrieved from http://www.bmvi.de/SharedDocs/ EN/Documents/federal-transport-infrastructure-plan -2003.pdf?_blob=publicationFile

Feldwisch, W., Drescher, O., Flügel, M., \& Lies, S. (2007). Die Planung der Neu-und Ausbaustrecke 
Nürnberg-Erfurt-Leipzig/Halle. Eisenbahntechnische Rundschau, 56(9), 494-500.

Fermi, F., Fiorello, D., Krail, M., \& Schade, W. (2014). Description of the ASTRA-EC model and of the user interface (ASSIST deliverable D4.2). Karlsruhe, Germany: Fraunhofer-ISI.

Florentin, D. (2010). The 'perforated city:' Leipzig's model of urban shrinkage management. Berkeley Planning Journal, 23(1), 83-95.

Girardet, H. (2015). Creating regenerative cities. Abingdon, UK: Routledge.

Großmann, K., Arndt, T., Haase, A., Rink, D., \& Steinfuhrer, A. (2015). The influence of housing oversupply on residential segregation: Exploring the postsocialist city of Leipzig. Urban Geography, 36(4), 550-577.

Haase, A., Kabisch, S., Steinführer, A., Bouzarovski, S., Hall, R., \& Ogden, P. E. (2010). Emergent spaces of reurbanisation: Exploring the demographic dimension of inner-city residential change in a European setting. Population, Space and Place, 16(5), 443-463.

Haase, D., Haase, A., Kabisch, N., Kabisch, S., \& Rink, D. (2012). Actors and factors in land-use simulation: the challenge of urban shrinkage. Environmental Modelling \& Software, 35, 92-103.

Haase, D., Schwarz, N., Strohbach, M., Kroll, F., \& Seppelt, R. (2012). Synergies, trade-offs, and losses of ecosystem services in urban regions: An integrated multiscale framework applied to the Leipzig-Halle region, Germany. Ecology and Society, 17(3), 22.

Hagen-Zanker, A., \& Lajoie, G. (2008). Neutral models of landscape change as benchmarks in the assessment of model performance. Landscape and Urban Planning, 86(3), 284-296.

Haghshenas, H., \& Vaziri, M. (2012). Urban sustainable transportation indicators for global comparison. Ecological Indicators, 15(1), 115-121.

Higgins, C., Ferguson, M., \& Kanaroglou, P. (2014). Light rail and land use change: Rail transit's role in reshaping and revitalising cities. Journal of Public Transportation, 17(2), 93-112.

Hortas-Rico, M. (2015). Sprawl, blight, and the role of urban containment policies: Evidence from US cities. Journal of Regional Science, 55(2), 298-323.

lacono, M., Levinson, D., \& El-Geneidy, A. (2008). Models of transportation and land use change: A guide to the territory. Journal of Planning Literature, 22(4), 232-340.

Jones, C. E., \& Ley, D. (2016). Transit-oriented development and gentrification along Metro Vancouver's low-income SkyTrain corridor. The Canadian Geographer, 60(1), 9-22.

Karou, S. \& Hull, A. (2014). Accessibility modelling: Predicting the impact of planned transport infrastructure on accessibility patterns in Edinburgh, UK. Journal of Transport Geography, 35, 1-11.

Kenworthy, J. R., \& Laube, F. B. (1999). Patterns of automobile dependence in cities: An international overview of key physical and economic dimensions with some implications for urban policy. Transportation Research Part A: Policy and Practice, 33(7), 691-723.

Lavalle, C., Barredo, J. I., McCormick, N., Engelen, G., White, R., \& Uljee, I. (2004). The MOLAND model for urban and regional growth forecast: A tool for the definition of sustainable development paths. Ispra, Italy: EC-Joint Research Centre.

Lavalle C., Gomes C. R., Mubareka S., \& Escobar, F. (2009). Procedures and protocols to upscale results from high-resolution spatially explicit development scenarios (PLUREL: D2.4.2). Brussels: EC-6th Framework Programme.

Litman, T. (2000). Evaluating public transport benefits and costs. Victoria, BC: Victoria Transport Policy Institute. Retrieved from http://www.vtpi.org/ tranben.pdf

Litman, T. (2016). Evaluating transportation land use impacts. Victoria, BC: Victoria Transport Policy Institute. Retrieved from http://www.vtpi.org.landuse.pdf

May, A. D. (2013). Urban transport and sustainability: The key challenges. International Journal of Sustainable Transportation, 7, 170-185.

Mills, E. S. (1967). An aggregative model of resource allocation in a metropolitan area. The American Economic Review, 57(2), 197-210.

Muth, R. (1969). Cities and housing. Chicago: The University of Chicago Press.

Nelson, A. C., Dawkins, C. J., \& Sanchez, T. W. (2007). The social impacts of urban containment. Aldershot: Ashgate.

Odgaard, T., Kelly, C., \& Laird, J. (2005). Current practice in project appraisal in Europe: Analysis of country reports (HEATCO D:1). Retrieved from http://heatco.ier.uni-stuttgart.de/hd1final.pdf

Organisation for Economic Co-operation and Development. (2002). Impact of transport infrastructure investment on regional development. Paris: OECD.

Pereira, A. M., \& Andraz, J. M. (2013). On the economic effects of public infrastructure investment: A survey of the international evidence. Journal of Economic Development, 38(4), 1-37.

Petrov, L., Lavalle, C., \& Kasanko, M. (2009). Urban land use scenarios for a tourist region in Europe: Applying the MOLAND Model to Algarve, Portugal. Landscape and Urban Planning, 92, 10-23.

Research Institute for Knowledge Systems. (2007). MOLAND transport model (Final Report of Contract 382463 FISC). Netherlands: RIKS.

Rink, D., Haase, A., Grossmann, K., Couch, C., \& Cocks, M. (2012). From long-term shrinkage to re-growth? A comparative study of urban development trajectories of Liverpool and Leipzig. Built Environment, 38(2), 162-178.

Schubert, T., \& Kniestedt, F. (1994). Erste weichen gestellt: Eisenbahn-neubautrasse ErfurtLeipzig/Halle. Baukultur, 3, 20-24. 
Schwarz, N., Bauer, A., \& Haase, D. (2011). Assessing climate impacts of planning policies-an estimation for the urban region of Leipzig (Germany). Environmental Impact Assessment Review, 31, 97-111.

Shahumyan, H., Williams, B., Petrov, L., \& Foley, W. (2014). Regional development scenario evaluation through land use modelling and opportunity mapping. Land, 3(3), 1180-1213.

Simmonds, D., \& Coombe, D. (2013). The transport implications of alternative urban forms. In K. Williams, E. Burton, \& M. Jenks (Eds.), Achieving sustainable urban form. London: Spon Press.

Stadt Leipzig (2016). Population pyramid Leipzig 2015. Leipzig: Office of Statistic and Election of the City of Leipzig. Retrieved from http://english.leipzig.de/ services-and-administration/leipzig-in-figures/popul ation

TEN-STAC. (2004). Traffic, bottlenecks and environmental analysis on 25 corridors (Project No. 14159000/ R20040194, D 6: Part I).

Turok, I., \& Mykhnenko, V. (2007). The trajectories of European cities, 1960-2005. Cities, 24(2), 165-182.

United Nations. (2016). New urban agenda (Resolution adopted by the General Assembly on 23 December 2016). New York: United Nations General Assembly. Retrieved from http://habitat3.org/wp-con tent/uploads/New-Urban-Agenda-GA-Adopted-68th -Plenary-N1646655-E.pdf

United Nations Human Settlements Programme. (2013). The state of the World's cities 2012/2013: Prosperity of cities. New York: Earthscan.

Ustaoglu, E., Williams, B., \& Petrov, L. (2012). Developing a CBA methodology for the scenario-based landuse impact assessment of proposed rail investments in the Leipzig Region. In M. Campagna, A. De Montis, F. Isola, S. Lai, C. Pira, \& C. Zoppi (Eds.), Planning support tools: Policy analysis, implementation and evaluation. Proceedings of the Seventh International Conference on Informatics and Urban and Regional Plan- ning INPUT2012. Milano: FrancoAngeli.

van Eck, J. R., Burghouwt, G., \& Dijst, M. (2005). Lifestyles, spatial configurations and quality of life in daily travel: An explorative simulation study. Journal of Transport Geography, 13(2), 123-134.

Westerink, J., Haase, D., Bauer, A., Ravetz, J., Jarrige, F., \& Aalbers, C. B. (2013). Dealing with sustainability trade-offs of the compact city in peri-urban planning across European City Regions. European Planning Studies, 21(4), 473-497.

Wheeler, S. M. (2013). Planning for sustainability: Creating livable, equitable and ecological communities. New York: Routledge.

White, R., Engelen, G., \& Uljee, I. (1997). The use of constrained cellular automata for high-resolution modelling of urban land-use dynamics. Environment and Planning $B, 24,323-343$.

Williams, B. (2014). Bailing out the banks: The role of the National Asset Management Agency (NAMA). In A. MacLaran \& S. Kelly (Eds.), Neoliberal urban policy and the transformation of the city. Basingstoke: Palgrave Macmillan.

Williams, B., \& Nedovic-Budic, Z. (2016). The real estate bubble in Ireland: Policy context and responses. Urban Research \& Practice, 9(2), 204-218.

Williams, K. (2005). Spatial planning, urban form and sustainable transport: An introduction. In K. Williams (Ed.), Spatial planning, urban form and sustainable transport. Hampshire: Ashgate.

Williams, K., Burton, E., \& Jenks, M. (2000). Achieving the compact city through intensification: an acceptable option?. In M. Jenks, E. Burton, \& K. Williams (Eds.), The compact city-A sustainable urban form? London: Spon Press.

Zondag, B., de Bok, M., Geurs, K. T., \& Molenwijk, E. (2015). Accessibility modelling and evaluation: The TIGRIS XL land-use and transport interaction model for the Netherlands. Computers, Environment and Urban Systems, 49, 115-125.

\section{About the Authors}
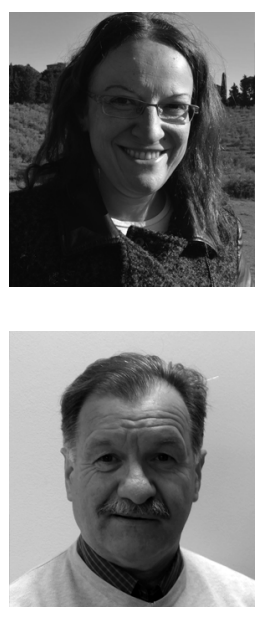

Eda Ustaoglu has a PhD in Planning and Environmental Policy from the School of Architecture, Planning and Environmental Policy, University College Dublin, and until 2015 she worked at the European Commission Joint Research Centre-Ispra as a scientific officer. Over the past ten years, she has been involved in various projects, university studies and research activities in line with her graduate and post-graduate studies, which are directly related to the field of urban and environment studies. Her research interests include urban and environmental economics, transportation planning and policy, transportation infrastructure appraisal, spatial economics, and land-use research.

Brendan Williams lectures in Urban Development, Urban Economics and Comparative Planning systems at the School of Architecture, Planning and Environmental Policy, University College Dublin. His principal research themes are urban development and policy frameworks in Ireland and internationally and applied research on the role of property markets in economic development. He is currently Head of Subject for Urban and Regional Planning and Director of the Urban Environment Research Project at University College Dublin. Dr. Williams is Associate Professor at UCD and Affiliate Professor to the National Center for Smart Growth at University of Maryland U.S. since February 2015. He has published approximately 100 scientific papers and edited/co-authored 6 books on various aspects of planning and development in Ireland and internationally. 
Laura O. Petrov is an experienced researcher in spatial planning, land-use change modelling and policy scenarios, territorial development, urban and regional sustainable development, applied research and regional, urban and environmental policies. Laura was awarded a PhD in Landscape Ecology by Hiroshima University in 2002. Since then, she expanded her international work experience as scientist at UFZ Centre for Environmental Research, University College Dublin and Aarhus University, as well as Scientific Officer at DG Joint Research Centre of European Commission in Italy and Statistical Officer at DG European Statistical Office of EC in Luxembourg. Laura is now Policy Analyst at DG JRC in Brussels where her work channels on European policy development in the context of regional policy and territorial cohesion, commission evaluations and impact assessment, particularly in support to the Better Regulation Agenda and REFIT programme. 